\title{
President Jacob Zuma and South Africa's Financial Crisis: A Machivellian Debacle
}

\author{
Anis Mahomed Karodia ${ }^{1}$, Paresh Soni ${ }^{2}$ \\ ${ }^{1}$ Professor, Senior Academic and Researcher, Regent Business School, Durban, Republic of South Africa, \\ akarodia@regent.ac.za \\ ${ }^{2}$ Institutional Research Manager, Management College of Southern Africa (Mancosa), Durban, Republic of South Africa \\ Correspondence: Anis Mahomed Karodia, Professor, Senior Academic and Researcher, Regent Business School, \\ Durban, Republic of South Africa. Email: akarodia@regent.ac.za
}

Received: February 22, 2016

Accepted: March 15, 2016

Online Published: May 6, 2016

doi:10.5539/ibr.v9n7p24

URL: http://dx.doi.org/10.5539/ibr.v9n7p24

\begin{abstract}
The paper is a continuation of a research article published in the same journal in the month of March, 2016. A new dimension has now entered the equation in terms of the fiscal and economic quagmire and, crisis that, South Africa is confronted with. The paper argues President Jacob Zuma's (South African President) Machiavellian tendencies in respect of moving from one blunder to another by removing the capable and performing Minister of Finance, Nene and replacing him with a novice in the form of David Desmond van Rooyen, a Parliamentary backbencher, and without any tangible experience. Former Finance Minister Pravin Gordhan was recalled as Finance Minister having served in this position from May 2009 to May 2014. This was a blunder of gigantic proportions. South Africa therefore had three Ministers of Finance within one week. The paper will attempt to unpack these and many other issues in this article which adds to the woes of South Africa's economic and fiscal crisis. Technically, the paper will argue that the Machiavellian President scorns the economy and, is obsessed with power at any cost.
\end{abstract}

Keywords: machiavellian, damages, economy, fiscal, chaos, markets, ratings downgrade, junk status economy, politics

The meaning of Machiavellian: "Political expediency is placed above morality and the use of craft and deceit to maintain the authority and carry out the policies of a ruler is described. Characterized by subtle or unscrupulous cunning deception, expediency, or dishonesty: He resorted to Machiavellian tactics in order to get ahead. Techniques used in respect of political manipulation. A cunning, amoral, an opportunistic person, especially a politician" (Jacob Zuma). (http://dictionary.reference.com/) (1979, 1986 Harper Collins: 1560 - 1570).

A. How the Story and Announcement of the Sacking of Finance Minister Nene Unfolded in South Africa: Announcement of New Ministers of Finance and Cooperative Governance and Traditional Affairs

On the $9^{\text {th }}$ of December 2015, the President of the Republic of South Africa Jacob Zuma announced the appointment of a new Minister of Finance, Mr. David van Rooyen. I have received many representations to reconsider my decision (No names of people or organizations were given). Playing to the gallery the Machiavellian President said that "As a democratic government, we emphasize the importance of listening to the people and respond to their views. (This is not true. It was only because the Rand took a dive of serious proportions and the loss of confidence by investors and international markets. It was also because of an uproar within the ruling party and ANC MP's, disgruntled with the President. The President and the ANC technically listens to no one but itself). In this regard, I have after serious consideration and reflection, taken the following decision:

\section{B. Finance}

I have appointed Mr. Pravin Gordhan the current Minister of the Department of Cooperative Governance and Traditional Affairs (COGTA) as Finance Minister (Note that he was removed only 18 months ago as Minister of Finance because of rifts with the President and, the desire of wanting a Black South African to be the Minister of Finance). He was Minister of Cooperative Governance and Traditional Affairs (COGTA), and is now the new Minister of Finance once again. Minister Gordhan will return to a portfolio that he had held proficiently during the fourth administration. He will lead government again in the following: 
$>$ Ensuring an even stronger alignment between the Budget and the Medium Term Strategic Framework (MTSF) in the interest of stimulating more inclusive growth and accelerated job creation while continuing the work of ensuring that our debt is stabilized over the medium term.

$>$ Promoting and strengthening the fiscal discipline and prudence that has characterized our management of public finances since the dawn of freedom.

$>$ Working with the financial sector so that, its stability is preserved under the broad umbrella of the Twin Peaks reform.

Ensuring that the National Treasury is more acceptable to all sections of our society.

$>$ Adherence to the set of expenditure ceiling while maintaining a stable trajectory of our debt portfolio, as set out in the February 2015 budget" (Emphasis added).

Such a statement allows for no confidence in the President and in spite of appointing the so - called competent Pravin Gordhan as Finance Minister, the damage to the South African economy has been done because, it is not about the competency of Gordhan when one considers the unnecessary removal of the likeable and competent Nene. It is more about an incompetent President and his cronies who support him within government and his hand - picked Cabinet, and give credence to his Machiavellian tendencies and behaviour.

\section{Cooperative Governance and Traditional Affairs (COGTA)}

I have also decided to appoint the current Minister of Finance, Mr. David van Rooyen (Who only held the position of Minister of Finance for one weekend and, in total four days) as the new Minister of Cooperative Governance and Traditional Affairs (COGTA). Mr. van Rooyen, a former Executive Mayor, will also be bringing to COGTA the finance and economic sector background gained in serving in the Finance Portfolio Committee and Economic Transformation Cluster as whip in the National Assembly. He has been mandated to take forward the Back to Basics Programme and, further improve cooperation between the three spheres of government. I wish both Ministers all the best in their new deployments" (Developing Story, ENCA News, SABC, (2015).

South Africa had three Ministers of Finance within four days. This is unimaginable in any other sane democracy and speaks to South Africa being turned into a "banana" republic by an incompetent and Machiavellian President and his cronies within the ANC. His appointment of Mr. van Rooyen is a travesty of justice because, he has no experience, is a novice and a political lightweight with no experience and, was only a failed mayor in the North West Province of the Republic and, is now called to run a very important department which is the face of service delivery (COGTA).

This is the statement of South Africa's Machiavellian and irrational President on the debacle that saw the Rand plummet and, over R194 billion lost in a matter of hours on the Johannesburg Stock Exchange and, a host of other reactions to the failing economy. The ANC said nothing after the announcement and the Secretary General and the Deputy President were conspicuously silent together with the Cabinet and the ANC working Committee. Suddenly on the $14^{\text {th }}$ of the month (December), the ANC announced its support for the President's action and said that the decision to sack Nene was taken six months ago. This is laughable and undermines the nation. The less said the better. It is the way the ANC governs and rules the country, singing the tune of the Machiavellian President or they must face his wrath. The Rand fell to an all - time low and the economy is now in tatters. The paper, under this background will therefore nuance the fiscal and economic crisis confronting South Africa, given the downgrade of the economy by the rating agencies (Fitch and Standard and Poor a month ago) and, the recent downgrade by Moody's (December) from stable to a negative economy and the downgrade of South Africa's four major banking institutions.

Given the announcement by the President of the sacking of a competent Minister of Finance (Nene), the graph below shows the market reaction to the sudden removal of the Finance Minister and indicates how the Rand fell off a Cliff:

How the Rand Fell of a Cliff

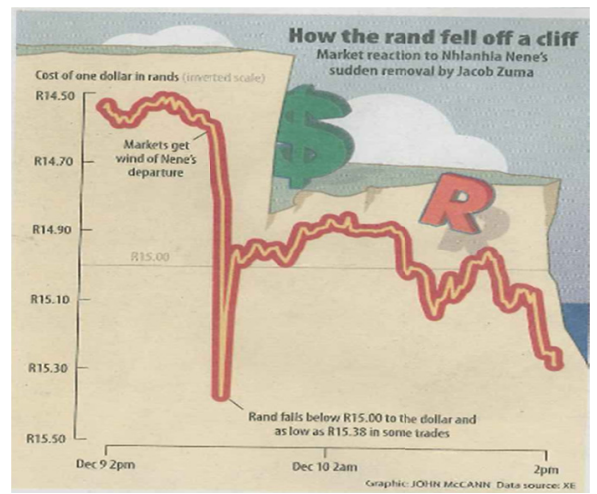

Source: Mail and Guardian. December 11 to 17, 2015. Johannesburg. Republic of South Africa, 2 


\section{Background and Introduction}

In a developing story in the media as breaking news (2015: 21 -48), the President fired a performing Minister of Finance who had served in this capacity for 18 months only and, was Deputy Finance Minister for five years, under the recalled former Minister of Finance Pravin Gordhan. Nene the fired Finance Minister was replaced for only four days by a complete backbencher and novice and, suddenly moved to the Department of Cooperative Governance and Traditional Affairs as Minister, a position occupied by Pravin Gordhan the new Finance Minister. "The perception in South Africa is that the reason for firing Nene was that he was doing his job well in difficult economic times, insisting on fiscal discipline," according to the Centre for the Study of Democracy (2015). He was reigning in the government in terms of fiscal prudence and would not accede to the Presidents desires for the propensity to spend in difficult economic times.

The President's irrational decision and Machiavellian behaviour not only raised eye brows, it booted the Rand into a tailspin, dipping below levels to the dollar never seen before. The Editorial of the Citizen (2015: 12) said that the "market was shocked as there had been little or no indication of the shock move. The consensus among analysts was that Nene had done a good job in difficult economic and fiscal circumstances. The move was even more shocking considering that a month earlier the rating agencies had downgraded South Africa's economy, to nearly 'junk' status." Nene tried to rein in recklessness at South African Airways (SAA), downplayed any excitement around the proposed nuclear build - was he too independent is the question? Was he too much of an obstacle when the need arose to miraculously find money for political decisions? There are rumours that, the strategic position Zuma mentioned in sacking Nene is a job at the Brics bank, but this is neither confirmed, nor logical by our Machiavellian President? Why risk chaos in the local fiscus to benefit a multinational bank? Zuma has done it again. He has failed to understand that by refusing to give cogent reasons for some of his Machiavellian decisions, he opens himself and his executive up to conspiracy theories and criticism. And the market is allergic to uncertainty. South Africa cannot afford, literally, to have a president who acts with disdain towards the sensitivities of the economy. Sarah Wild (2015: 13) says that the president of South Africa is "toxic", someone who engages in behaviour that is harmful to the organization (The Republic of South Africa), including either its property or people. It causes market fear, low morale, major costs, turnover and loss of legitimacy among external and internal stakeholders." This is what the President of South Africa has achieved in respect to his decisions. He is self - regarding and shows little concern for other's interests and has not refrained from damaging people. In other words the President of South Africa cannot be reformed. Sarah Wild (2015: 13) states that "There is strong evidence that Machiavellianism leads to deviant behaviour."

The Nene bombshell according to Lisa Steyn and Lynley Donnelley (2015: 1) "shattered investor confidence and mauled the South African Economy." Not even the African National Congress (ANC) top six executives knew about the president's shock decision. The market value of South African bonds fell by R56 billion and who will stop this wrecking ball created by the Machiavellian President? The graph below shows how South Africa's economic prospects quickly worsened, after Nene was axed and, government borrowing costs surged to higher levels, indicating South Africa's 10 year bond yield:

How SA's economic prospects quickly worsened

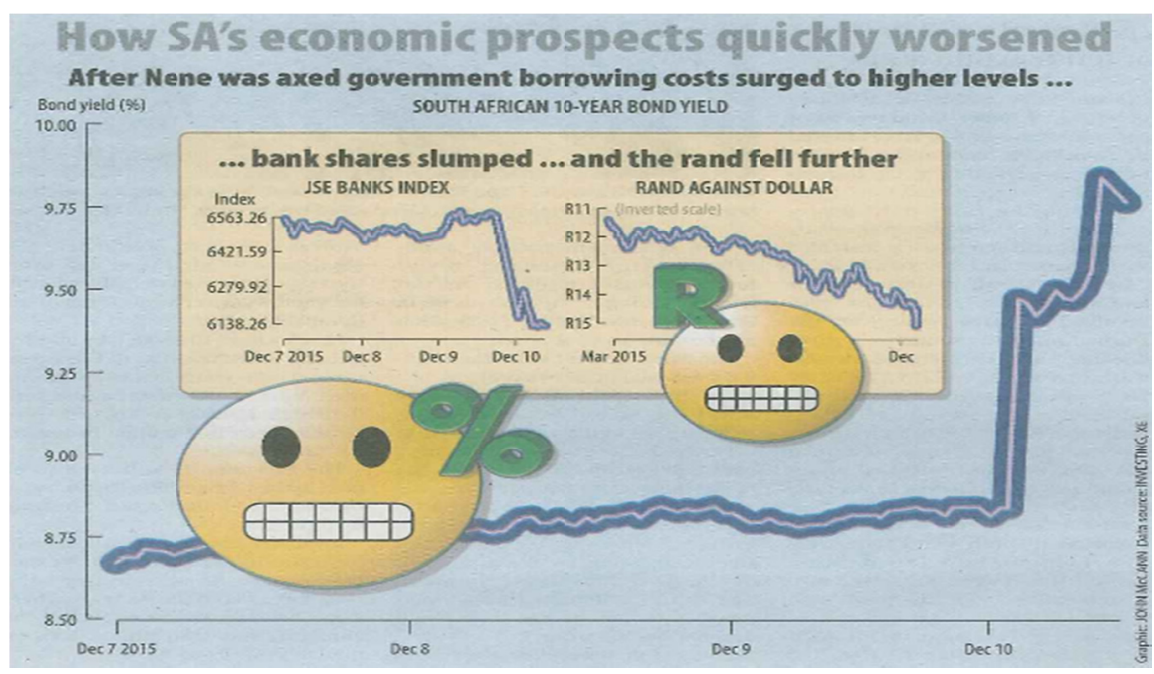

Source: Lisa Steyn and Lynley Donnelley: Mail and Guardian Business, 1 
Instantly, the Rand, a key measure of confidence went to crisis levels and the currency had its biggest single fall since the events of 9/11 fourteen years ago according to Bloomberg" (In Lisa Steyn and Lynley Donnelley, 2015 1). Borrowing costs in the bond market leaped, and the major state-owned entities, such as Eskom, which are already battling financial crises, are expected to come under enormous pressure. Analysts in the South African press "predicted Nene's firing would push the country into a recession and reduce its investment status. Interest rate increases to protect the currency are likely, as is an increase in inflation and job losses. Tax hikes in the next budget could well follow" (Lisa Steyn and Lynley Donnelley $(2015,1)$. Nene's removal has been viewed as an attack on the credibility of the Treasury, which is seen as a bastion of good governance within the state. There are now fears that the South African Reserve Bank could be next in line.

The Treasury has wielded the Public Finance Management Act (PFMA) like a sword to curb wasteful and corrupt spending. There are very serious questions over why Zuma chose to replace the well - respected technocrat Nene, as well as questions over the timing. The announcement came hot on the heels of credit ratings downgrade and, at a time when adverse global events are looming, such as the widely expected decision by the United States Federal Reserve to raise interest rates. Nalla (2015, In Steyn and Donnelley) said that "investors are likely to be concerned about institutional erosion. The reason as to why South Africa has been rated more favourably than other emerging markets has been because of the independence of the South African Reserve Bank, the Treasury and the judiciary." We now chip away effectively at the national treasury being a cornerstone of fiscal consolidation and, it being a framework for economic recovery in very trying times. Therefore, South Africa has now created the framework of slipping into an economic recession next year, in 2016 because of the Machiavellian stance of the president. There can be very serious down - side growth risks. What the president did not factor into the equation when he fired Finance Minister Nene was that, interest burdens would increase for the country as would the value of capital repayments, because all new items were priced in foreign currency. In short he was fired because he did not support Zuma's expenditure plans for SAA (South African Airways) and, the nuclear deal with Russia and China. (He promised the Russian President of the deal in a clandestine visit to the Russian Federation, in 2014 and, was now becoming impatient because Nene would not allow the spend on the nuclear programme). It is obvious that the small tax base now faces personal income taxes to fund the ANC and, the presidents wasteful spending plans, particularly given that the taxpayers are not typically ANC voters. The biggest test and issue is for so - called comrades within the National Executive Council of the ANC to stand - up against the irrational and Machiavellian and illogical behaviour of the president which has become the hallmark of his tenure. It is time for all reasonable voices within the ANC to stand up and say that you Mr. President must resign or allow us to recall you like it was done to President Mbeki and, state categorically and emphatically that enough is enough. In 2008 the crisis was global but in this case the focus is squarely on South African politics. Now we see that "the 10 - year bond yield had been re - priced given the debacle, by 60 points, moving from 8.8 percent to 9.4 percent. It translates into a 4 percent loss in overall bond value and that market capitalization of government bonds was at R1.4 trillion before, and so R56 billion in market value had been eroded in a matter of hours" (Steyn and Donnelley, 2015).

Although much of the government debt is fixed, the cost of any newly accumulated debt will be higher. The rising government bond yield could raise the cost of borrowing offshore substantially and will affect state - owned enterprises such as Transnet. These are difficult policy decisions because of political uncertainty there is a drastic risk premium and, therefore, a full blown currency crisis cannot be ruled out. Zuma's decision also elicited shock from across the political spectrum. South Africa is now adding the ingredients to be classed as a failed state. According to Hoffman (2015 in Steyn and Donnelley) "the ingredients of a failed state are essentially when the rule of law is replaced by the rule of men." This is precisely what has happened in South Africa under a Machiavellian President and his political patronage allies that have been placed in powerful portfolios and, sing to his tune or are in danger of losing their jobs. It is now most clear that Nene was pushed because he was at odds with Zuma and the Energy Minister on the nuclear build programme and, was at odds with the presidency in relation to the purchase of a R4 billion jet for his personal use and, in addition was at odds with the Chairperson of SAA, also known to be a close associate of President Zuma. It is a question of hegemonic control by the Machiavellian President of the Republic. The firing of Minister Nene has also begun to hurt South Africa's private sector. Bloomberg (2015) indicated that" South Africa's banking index plummeted to levels on a par with the 2008 global financial crisis. First Rand Bank fell by 10 percent, the Standard Bank Group by 9.1 percent, Absa Bank by 9.2 percent and the Nedbank Group by 6.6 percent."

NOTE: It was necessary to unpack the history of this paper in the introduction, in order to set the tone of the discussion that will be undertaken in this narrative.

\section{Methodology}

The paper does not use any specific and classical methodologies that are usually used in research. This is because the paper is an analysis of the economic and fiscal crisis that has befallen South Africa, due to the Machiavellian decision of firing the capable Finance Minister Nene. The paper therefore, uses newspaper articles in the main to analyze the 
economic situation and fiscal crisis in South Africa and shows that, this decision led to a market crisis, damaged the Johannesburg Stock Exchange (JSE) which shed R194 billion in a matter of hours and hit and hurt ordinary citizens in their pockets. Investor confidence was severely dented and destroyed as the Rand bled by alarming proportions as compared to the United States Dollar, the Pound Sterling and the Euro (R16; R23; R18.50 respectively). It called in the South African Reserve Bank which now had to ensure that the market ructions did not snowball into a full blown crisis for the economy. The paper will therefore, analyze the fiscal and economic situation in South Africa following this Machiavellian debacle and, in so doing the researchers will use their own analytical skills and observations, in order to place this narrative in perspective because the South African economy will most certainly move towards being inevitably declared a ' junk' status economy. (Readers must also read the paper on the economic and fiscal crisis published in the March, 2016 copy of this journal, in order to get a better understanding of the economic and fiscal quagmire that South Africa is now in).

\subsection{Aim of the Paper}

The aim of the paper simply put is to analyze the consequences of the dictatorial and Machiavellian behaviour and decision by the South African President, to fire a capable Minister of Finance, which has resulted in very serious damage to the South African nation and, by implication to an already bleeding economy.

\subsection{Objectives of the Paper}

There are few objectives that the paper sets out to discuss. Amongst the more salient issues the following are considered important:

$>$ To review the irrational, dictatorial and Machiavellian behaviour and decision by the President of South Africa to fire the Minister of Finance.

$>$ To analyze the consequences of this decision on the economy of South Africa and to discuss the fiscal crisis.

$>$ In addition, the paper will look at the internal consequences that have now befallen the African National Congress (ANC) as the party that governs South Africa, post democracy, since 1994 and the dire consequences that will most certainly affect the ANC at the 2016 local government elections.

$>$ Analyze the role of the South African Airways (SAA) Chairperson that dictated the demise of the Finance Minister who refused to bailout the airline from its financial woes which led to him losing his job.

$>$ Look at the unconvincing nuclear deal that South Africa is to enter into in the New Year at a cost of over R1.4 trillion which made the Finance Minister, block the deal and place South Africa into a phase of economic recovery by means of very prudently dealing with fiscal consolidation, which brought about the ire of the President, because the nuclear programme was an almost done deal with Russia, without the realization by the President that South Africa could not monetarily afford the nuclear programme.

$>$ To place in perspective the influence of an immigrant family of three brothers that have tremendous influence on the President, in order to serve their greed and feed the monetary appetite of the President and his family by means of ill - gotten gains.

$>$ The paper will also look at the President's, 2016 State of the nation address and determine, if he chartered a course of economic revival to save South Africa from being declared as a junk status economy by ratings agencies.

$>$ The paper amongst the above variables will look at a host of other issues that are pertinent and relevant to this narrative.

\subsection{Conclusions and Recommendations}

There are no finite conclusions and recommendations that the paper will undertake or make. This is because the conclusions are within the public domain and therefore, the conclusions and recommendations will be dispersed throughout the narrative. These will be highlighted throughout the discussion undertaken in this paper. There will, however be some conclusions and recommendations made at the end of the paper by the authors.

\subsection{Ethical Considerations}

The researchers did not have to subject the paper to any ethical considerations because; the issues raised in this paper are already in the public domain, both domestically and internationally. To this end the government of South Africa has also responded to the Machiavellian debacle that the country is now confronted with. In this sense the narrative is a factual analysis of the economic and fiscal crisis that has befallen South Africa and, therefore, ethical considerations bear no relevance to the discussion undertaken in this narrative. South Africa economically interacts with international rating agencies and other international economic bodies in terms of risk assessment and, is therefore, woefully aware of 
the possible consequences that would result from the mismanagement of the economy.

\subsection{Areas for Further Research}

There is no doubt that this paper cannot capture all the subtle nuances that encompass this very serious and lengthy issue, in terms of its social, political, cultural, economic, fiscal and historical relevance. Greater work and more sustained research will have to be undertaken by other researchers, using classical research methodologies to unpack the dire consequences of the President's decision to fire the Minister of Finance and, its impact on the economy of South Africa. In so doing such research must encompass some of the issues delineated hereunder:

$>$ Analyze the economic and fiscal situation of South Africa post 1994 from the inception of democracy to the current situation.

> Place in historical perspective the management and mismanagement of the South African economy after, 21 years of freedom and liberation from the yoke of apartheid oppression, by the ruling ANC led government.

$>$ To compare the country post democracy under different Presidents and their Ministers of Finance, in terms of the management of the economy and its objectives of fiscal consolidation.

$>$ To determine how South Africa lost its way, in terms of cadre deployment, the abuse of public funds, the vulgar increases in public servant salaries, the burden of loss - making state - owned enterprises, the electricity and water crisis and so on.

$>$ In addition the research must indicate the consequences of funding loss - making projects.

$>$ Given the economic crisis an in depth analysis of the necessity of the nuclear programme must be researched. In addition the proposed implementation of the National Health Insurance (NHI) programme must also be researched fully, in order to analyze universal health coverage and as to whether South Africa can afford its implementation currently, or is it ready to implement the programme.

$>$ If education is a public good that, must be guaranteed by the government of the day, why has it not been rolled out at both the basic and higher education levels after democracy in 1994? The costs for free education must be worked out by such research, in keeping with the dictates of the ANC's Freedom Charter, which categorically states that the doors of learning must be open to all.

$>$ Outline the high road to development and the low road scenarios that has hampered and stymied development in post - democratic South Africa.

$>$ Look at government wastage in terms of funds. In addition determine why corruption has become endemic within the body politic of South Africa and, research must show what the consequences are upon the economy and development of South Africa.

$>$ The research that will be undertaken must for all intents and purposes speak to the issues that permeate sound governance and encompass the important issues of accountability and the rule of law, in terms of the Constitution of the Republic.

$>$ The research must determine as to how South Africa can afford a bloated and inefficient public service with rising uncontrollable salaries that now makes up almost 60 percent of GDP.

$>$ The above issues are only the tip of the iceberg in terms of South Africa's fiscal and economic quagmire and therefore, comprehensive and, in depth research must be undertaken, in order to make succinct conclusions and recommendations to the South African government with the aim of turning the South African economy around, with the aim of placing the country onto a strong and desirable growth path, in a sustainable manner for purposes of making the country economically viable.

$>$ Research must also be undertaken in respect of the high unemployment rates in South Africa, increasing inequality and rising poverty post 1994 , to determine, the widening gap between the rich and the poor and, to determine how the ruling elite has hijacked the development of the country because, of its own interests and propensity for wealth accumulation at the expense of the people.

$>$ Research any other issues relevant and applicable to economic stability, sustainability and investigate the need to fill the large gaps being experienced in respect of management and skills deficits inherited from the apartheid government and, by the democratic governments own making over 21 years of freedom.

Naturally, not all of the above issues could be encapsulated in a single piece of research. It is therefore suggested that the above issues be clearly delineated and structured, in order to conduct relevant and cogent research in two or three in depth papers or be approached as a full independent research project in the form of a report. 


\section{Conclusion}

The paper basically projected on the sacking of a competent South African Minister of Finance by the President of South Africa, without furnishing any tangible reasons for his decision. The South African economy was severely dented and, the country is now on the verge of being declared a 'junk' status economy by rating agencies, that are renowned for assessing the risks attached to economies in general. It points to the reality that the President of South Africa is a dictator that doles out positions on the basis of political patronage, in order to remain in power and, this allows for his Machiavellian behaviour and, has the support of the ANC leaders because, no one can stand up to him because they will lose their jobs. Clearly the President by his irrational decisions has placed the South African economy and, its people at great economic risk. Plainly put he just does not understand how capitalist markets function, nor does he understand the pathways of the capitalist economy. The President's 2016 State of the Nation Address will be analyzed in order to determine, if the government of South Africa has an economic recovery plan for the country. Primarily the objective of the paper is to determine, if South Africa can avoid the inevitability of its economy being downgraded to junk status by ratings agencies. It appears that, the Finance Minister when he presents his 2016 / 2017 budget would not be in a position to turnaround the South African economy from avoiding, a junk status rating.

\subsection{Discussion: The Low Road of the South African Economy}

\subsubsection{All except the ANC Slams the President over Ill -Timed Sacking of Finance Minister Nene}

Denise Williams (2015) reports that "Unions, religious organizations and political parties have slammed President Jacob Zuma's decision to fire the Finance Minister and, only the ANC has publicly respected the decision. Cosatu, (The Congress of South African Trade Unions) the largest union federation, indicated that the decision was ill - timed. The economic sector did not cope well with abrupt and unqualified changes. The unemployment rate is going through the roof and the blight of capital flight is back in full swing." Cosatu feels that what is wrong with the Treasury is that the mandarins and technocrats have too much power and they are neo - liberal hardliners. Such statements do the economy no good because Cosatu has become a mouth piece of President Zuma and in reality, it has become a non - workers union that has divisions amongst itself, and, has miscalculated the decisions of the Machiavellian President which has had a serious impact on the South African economy. The South African Treasury is doing an outstanding job and no amount of criticism of the Treasury will be bought by the population and, the rating agencies including investors. Opposition parties according to Denise Williams (2015) "have been united in their opinion that Nene was axed unnecessarily because, he opposed bailing out the struggling SAA, (South African Airways) to help the Presidents close friend Dudu Myeni the airlines boss." The Cabinet and ANC formations do the country a serious disservice and are assisting the Machiavellian President to lower South Africa to the lowest common denominator and, are destroying what is left of its rich struggle credentials. South Africa has become a "joke" and "laughing" stock in the eyes of the world, as democracy is being slowly but surely eroded under the ANC ruling government and, it's Machiavellian President. The President's decision comes amid a worsening economic crisis inside the country and Africa's most industrialized, which is going through an unemployment crisis, the decline in the Rand, energy regeneration and water shortages. Azikiwe (2015) states that "the appointment of successive finance ministers has been met with trepidation by the corporate interests while Anglo American mining conglomerate announced that it would eliminate 85000 jobs in a major restructuring plan. These developments represent an ongoing process of job losses in the extractive industry, a major source of employment and foreign exchange earnings within the South African and regional economies. In 2016, this situation would spread to other coal and gold mines." The Machiavellian President and his coterie of yes men within the Cabinet have not understood and pay scant reference to the already escalating class struggle inside the country. There has been very slow distribution of wealth during the post - apartheid period. Azikiwe (2015: $1-2)$ further points out that "The South African economic crisis is a reflection of the downturn among numerous emerging states which have experienced substantial growth over the last decade. A decline in commodity prices, including oil and other natural resources, has illustrated the continuing dependency on the existing capitalist dominance of the world system." South Africa and its President feed directly into this system serving their own personal interests and, at the expense of its majority poor population. In other words the removal of a respected, fiscally conservative finance minister is a serious blow to investors.

\subsubsection{The Nuclear Deal is a Minefield}

De Wet and Sole (2015:) report that "Earlier this year, the Energy Minister insisted that the planned fleet of nuclear power stations that, is to add 9600 megawatts of nuclear energy to the grid by 2030 was affordable, even though funding models had yet not been completed." The numbers do not look good and rough estimates put the top end of the nuclear bill at $\$ 100$ million dollars which in Rand terms was considerably more given the President's announcement of the new Finance Minister, which resulted in the slump of the currency. According to De wet and Sole (2015) "Russia has offered to provide vendor financing for the full build price, and China and perhaps others are expected to do 
likewise. Under the mooted Russian finance model, South Africa would pay back the capital cost of construction over 20 to 30 years, though the repayments would only come due when the first reactor comes on line. But with debt denominated in dollars, the risk to South African taxpayers would be enormous, even if the money could be found for the expected repayments, in a budget stretched by the demands of healthcare, education and civil servant salaries." In other countries interest rates for similar deals have run between 4 percent and 5 percent. In respect to the nuclear deal many have fallen on the wayside for not acceding to the President's demand. It is understood that financial assessments procured by the Treasury have stressed the dangerously high risk and cost of nuclear power, despite efforts by Zuma's chorus to sing a song of affordability. In this regard Nene was holding the line of no. So he had to go. South Africa has other pressing priorities that need to be addressed and, therefore, the nuclear deal must be shelved for now.

\subsubsection{Cabinet Gives Green Light to Nuclear Procurement}

The above decision was made before Nene's shock dismissal and the Cabinet instructed the Department of Energy to call for proposals to provide South Africa with 9.6GW of nuclear power without first doing a cost - benefit analysis" (Paton, 2015). The programme is controversial as several independent studies have found that the cost of new nuclear energy will be greater than energy produced by other technologies. Paton (2015) states that there "is a deep suspicion that the procurement will be corrupt, with Russia claiming some time ago that it had already struck a deal with South Africa. If South Africa goes ahead with its large nuclear procurement plan, it will be seen as another credit - negative factor by rating agencies. Carol Paton (2015) states that "in October, the Treasury allocated R200 million in dire economic circumstances to the Department of Energy to assist with a feasibility study and to procure transaction advice. At the time, the Treasury said this was to be used to consider costs, benefits and risks of building additional nuclear power stations. There is no evidence that a cost - benefit analysis was done." This is sufficient proof that the Minister of Finance Nene, was removed from office because he refused the nuclear spend and that after his removal, the door was wide open for Cabinet to push the proposal through the auspices of a four day handpicked Minister van Rooyen and, before the new Minister of Finance Gordhan was reappointed. The Machiavellian President has got his way and, has not taken the economic plight of the nation into consideration. The Cabinet in the majority made up of "yes men and women" of the President and, appointed on the basis of political patronage, do South Africa a great disservice in very trying economic times. In spite of requests by a host of role players including the press to release the KPMG report on the benchmarking of the cost of nuclear power, an Ingerop study on the cost of nuclear plants and proposed ownership models; and a Deloitte study on the financing of nuclear power plants. In terms of the Access of Information Act, Business Day in August of 2015, requested copies of these reports from the department but was told they were classified." This is the way of the ANC led government, to skirt very important issues that affect the country and pay scant reference to the tenets of democracy. Carol Paton (2015) states that "The department has said its studies show that nuclear energy is affordable. But Business Day understands that, the Deloitte and KPMG studies found to the contrary; the substantial amounts in debt and equity from the state will be required. In addition, none of the studies analyzed the levelised cost of nuclear energy in relation to other technologies. Three independent studies, one by researchers at the Energy Research Centre at the University of Cape Town; one by the Centre for Scientific and Industrial Research; and one by an engineer at the University of Stellenbosch, all published in September 2015, found nuclear energy to be more expensive than other base - load options." Government has to do the research. All of this must point to the feasibility of the introduction of nuclear power in South Africa and, if the findings are negative, President Zuma the Machiavellian President together with his Cabinet must be stopped in their tracks, in the interests of the country.

\subsubsection{Axing to Hit Life Savings Hard, Stock Exchange Boss Warns}

The life savings of South Africans would be severely affected by the unprecedented market movements in the aftermath of the removal of the Finance Minister Nene. This must be a warning to the President and his Cabinet. In this regard Marrian (2015: 1) states that "Business leaders said the economy and society faced their toughest challenge since 1994 and, therefore, it was imperative to determine whether the government remained committed to the National Development Plan and, its prudent fiscal and monetary policies.” The Machiavellian Jacob Zuma's flurry of denials and explanations for Nene's dismissal failed to convince the markets and investors. Academics urged Zuma to provide a more credible explanation for the move. Newton king (In Marrian, 2015) said that "Market losses put strain on credit extension and interest rates, and raised borrowing costs, which will result in mammoth costs for companies and individuals. This will constrain growth stimulus which is desperately needed. The possibility of much - needed job opportunities would diminish and higher lending rates would make life more expensive for ordinary South Africans.

In terms of the above discussion, the three graphs below shows clearly as to how the South African economy and fiscal crisis was exacerbated by the firing by President Zuma of the competent Finance Minister Nene and, as to how the Machiavellian Zuma put South Africa into a most precarious economic position. This blunder will take South Africa years to recover but, this is unlikely in the medium term because the damage has already been done, which will wreak havoc on the South African economy, for many years to come and, this situation will affect the country drastically and 
affect future generations which are in the main ill - educated and poverty stricken, looking for opportunity and wanting to come out of the poverty trap after 21 years of so - called democracy. These graphs show how South Africa was put into the Abyss and, are as follows:

Into the Abyss Graph 1, Graph 2, Graph 3

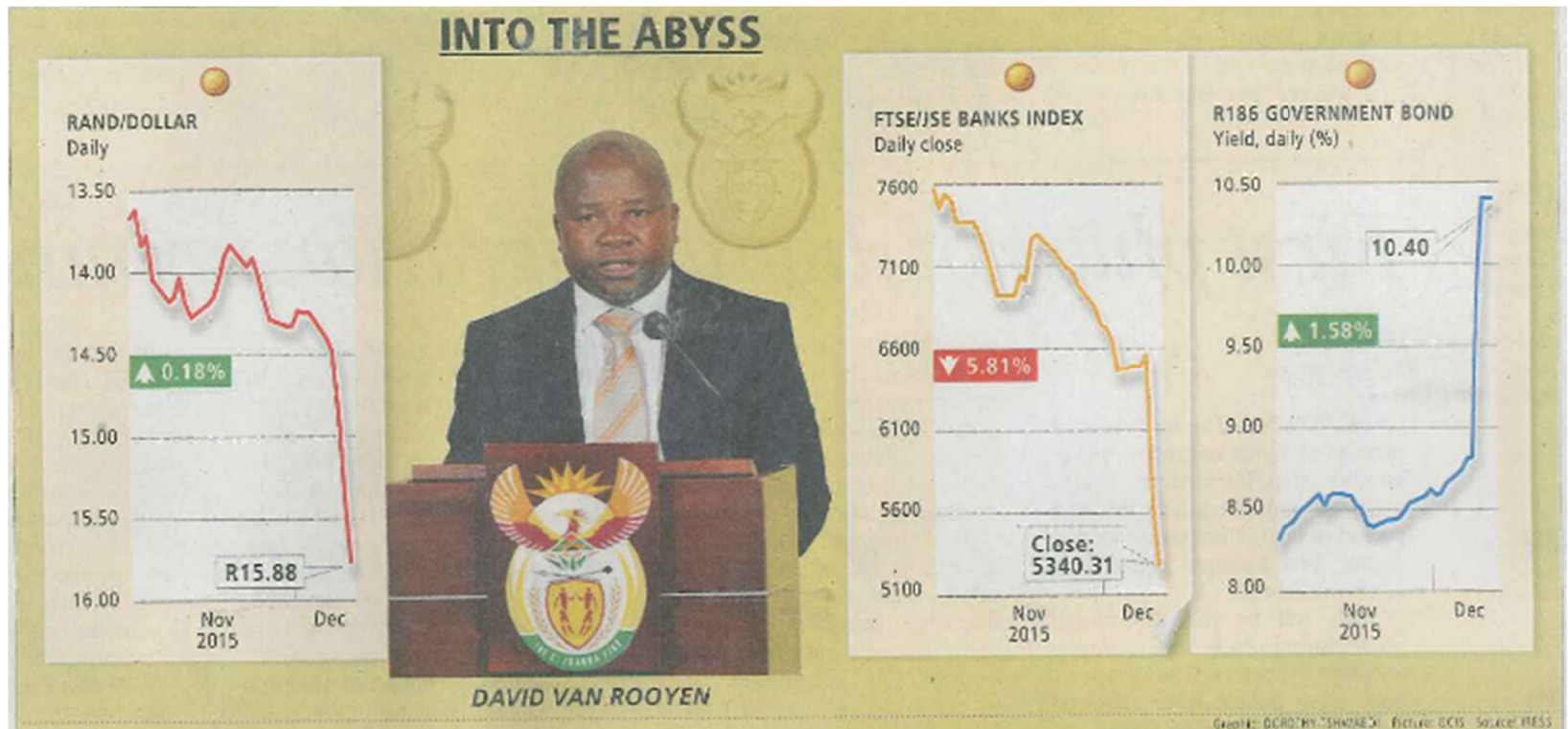

Source: Business Day, December 14. Johannesburg. Republic of South Africa, 1.

The continued depreciation of the Rand is set to have a profound effect on petrol prices and inflation, which would hurt companies, small businesses and individuals. Marrian (2015) indicates that "individual retirees to huge pension funds saw the value of their holdings plummet. It is disingenuous and wrong to attribute the poor performance and declining trend of the economy solely to global economic factors. In recent years, investor perceptions and confidence had been undermined by inappropriate regulations and by poor governance of key state institutions." On the other hand Bisseker (2015: 2) showed that "141000 jobs were lost year on year in the community services sector (a proxy for government). This may reflect an exodus of staff over policy uncertainty regarding pension reform. Producer Price Index (PPI) for November rose substantially to 4.2 percent year on year in October from 3.6 percent on year in September, mainly reflecting rising food prices due to the continued drought. All of this will definitely add pressure to the Reserve Bank's decision to further raise interest rates. Given these scenarios, it is important to reflect upon the Machiavellian President Jacob Zuma's economic-wrecking legacy. The firing of Finance Minster Nene came as economic policy mismanagement reached a new low. In this regard Zibi (2015) states that "Under normal circumstances, 2015 would be a year President Jacob Zuma would like to forget. This year saw the culmination of six years of economic policy mismanagement and dithering that sapped the confidence of business to invest and led to most economic and fiscal indices pointing in the wrong direction. His reasons for firing Nene remain unconvincing." Since Zuma ascended to the presidency in 2009, unemployment has risen from 23 to 25 percent whist other sources put the unemployment rate between anything from 40 to 45 percent. In addition the following variables have to be taken into consideration during the President's disastrous tenure. These are as follows:

$>$ "Youth unemployment his anchor programme six years ago has increased from 33.7 percent to 35.5 percent. The five million jobs promised were a pipe dream and nothing tangible, in this regard materialized.

$>$ By contrast under his tenure the biggest growth in employment has been the public service. The public service now accounts for nearly 60 percent of the government's budget expenditure. The contingency reserve, money the Treasury appropriates for rainy days, has been depleted to pay higher - than expected public servant salary increases.

$>$ His Cabinet employed more bureaucrats who have been unable to produce the economic growth, his allies on the left promised when they rejected a discussion document on fixing the economy.

$>$ His government has borrowed and spent more money than at any point in the past decade. Over R750 billion has been for infrastructure, industrial policy interventions have tended to be defensive to reduce retrenchments rather than create new jobs.

$>$ The water infrastructure has been destroyed, so has electricity generation under his watch. The water infrastructure will require over R800 billion over the next ten years to repair, whilst electricity will require tremendous amounts of money to remedy running into billions, if not trillions of Rands. 
$>$ Debt service costs are now the fastest growing national expenditure item. The debt to gross domestic product (GDP) ratio is at more than 60 percent and, is at levels last seen in the 1990s, when South Africa was saddled with apartheid -era debt. The economy is growing at a snail's pace, a galaxy away from Zuma's target of 5.4 percent contained in the National Development Plan (NDP).

$>$ South Africa will be very lucky if the economy grows anything higher than 1.3 percent in the coming years (It has been downgraded by rating agencies and the International Monetary Fund (IMF) to 0.8 percent for 2016). The growth rate has been revised downwards for all but one of the six years that Zuma has been in charge.

$>$ The current account and trade deficits have the effect of corroding the value of the Rand, which in turn puts pressure on domestic producers at a time when energy and labour costs are rising fast.

$>$ The European Union, South Africa's second biggest trading partner is going through a period of close to zero growth. The combination of this with China's contraction has dented South Africa's exports, while imports have accelerated.

Anglo America announced huge cuts across its global business including in South Africa.

$>$ Under Zuma's watch companies across sectors have no room to accommodate political pressure anymore.

> After six reshuffles of his Cabinet and, a progressively worsening economy and fiscal position, Zuma may have run out of aces. Far from factions and foreign agents conspiring against him, his biggest challenge, is the economy and, the honey it is no longer able to produce, may be his undoing.

$>$ The Machiavellian President Zuma's administration's policy contradictions have therefore ruined the economy. Dancing left but walking centre has meant that it is never quite clear what it wants to do. Some policy options, such as mining and tourism have been catastrophic.

$>$ By the same token the \#FeesMustFall protests sees the higher education landscape in turmoil and this will unravel even further in 2016.

$>$ The much talked about National Health Insurance Plan (NHI) for purposes of necessary universal health coverage will run into trillions of Rands to implement. It would have to be put on hold because there is no money and above all, it is a half - baked plan, and that the public health sector is in tatters and currently provides mediocre health services to the population of South Africa.

$>$ In firing Finance Minister Nene, Zuma acted to save the R1 trillion and more nuclear promises to Russian President Putin and has played Russian roulette with South Africa" (Summarized from a host of articles that appeared in the South African press. 2015 and 2016).

\subsubsection{Nene Axing a Warning to the Deputy President Cyril Ramaphosa}

Speculation is rife that President Jacob Zuma is neutralizing his critics to anoint his ex - wife Dlamini Zuma as the next ANC leader. The Deputy President has been conspicuously absent from taking any stance on Nene's firing and tensions are bound to deepen, ahead of the ANC's 2017 elective conference. The Mail and Guardian (2015) reports that "the decision to remove Nene is seen by some within the ANC - led alliance as a move to neutralize Ramaphosa and to consolidate his power before the party's next leader is elected. The ANC Secretary General was very unhappy with the President firing Nene. Zuma has indicated several times that the country was ready for a woman president and Letsoalo reports that the "President has privately said that he did not want Ramaphosa to replace him as party president. Nene's removal serves as a warning to others and particularly Ramaphosa, who was close to the Finance Minister (Nene) or they will be meted out the same treatment as Nene." In September, Nene rejected SAA's application for a R5 billion bailout. Letsoalo (2015) states that "ANC and government sources said that Zuma was becoming increasingly uncomfortable with the cordial relationship that was developing between Ramaphosa and Nene. Zuma supporters believe that Ramaphosa and Nene had been plotting to remove SAAs controversial chairperson, Dudu Myeni a close ally of Zuma's to further their own personal interests. Zuma supporters have also complained about Nene's continued relationship with former Ministers of Finance Pravin Gordhan and Trevor Manuel. Nene's removal now starts the possibility of a major reshuffle of Cabinet as fears grip the government."

\subsubsection{Nene Joins Myeni's Pile of Victims}

Irrespective of government's damage control in the wake of the Machiavellian Presidents illogical and irrational decisions over time, it is clear to see that the South African Airways (SAA) runway is littered with its chairperson's high - profile casualties. Among these was Vuysile Kona, the airline's acting chief executive, Malusi Gigaba the Public Enterprises Minister, Kalawe who replaced Kona as Chief Executive. The Minister of Public Enterprises Lynne Brown who replaced Gigaba, who was sent to Home Affairs, was sidelined because of her run-inns with Dudu Myeni. Minister Brown according to AmaBungane reporters (2015) said that "Brown told journalists at the time that she had instructed Myeni to reverse Kalawe's suspension and had demanded to hear from the board, why they were not listening to me .. I could not see any reason to suspend him. Myeni ignored Brown and SAA was taken away from her and put in the care of the finance ministry." Since these shenanigans and the power of the SAA chairperson, the Mail and Guardian 
(2015) reports that "SAA directors Barry Parsons and Tony Dixon, finance chief Wolf Meyer has left the company, and its commercial chief has been suspended, as has the procurement chief and many more are being investigated. Nene, who would not accede to Myeni's wish to alter a carefully negotiated deal in favour of one involving shady middlemen, is another victim in a long line."

\subsubsection{ANC's Allies Demand to be Consulted}

Contrary to governments carefully crafted statements and the president's support from within the ANC and his Cabinet supporters in agreeing with the President's decision to axe the Finance Minister Nene, the South African Communist Party (SACP) and the Congress of South African Trade Unions (Cosatu) want the tripartite alliance and, not just the ANC, to be strategic decision makers. This is a clear indication that that the tripartite alliance is in disarray and remain unhappy of the Machiavellian Presidents poor political judgments on many issues including the firing of Nene. Letsoalo (2015) states that "The ANC's alliance partners have warned President Jacob Zuma of the dire consequences of removing left-wing leaders. Many had indicated that they will be targeted and expressed fears that the growing tensions between nationalists and communists were the main reason. Cosatu and SACP leaders told the Mail and Guardian (2015) that "they expected Zuma to consult with the ANC's alliance partners on key decisions, including the reshuffling of Cabinet and the deployment of cadres in senior positions. Those that are deployed should be reminded that they are accountable to the alliance said South African Democratic Teachers Union (SADTU) General Secretary. In other words the alliance should be the strategic centre and not the ANC. We are calling for equality in determining deployment and key decisions. If this is not agreed to we go for elections said the ANC alliance partners."

\subsubsection{The Comedy of Errors}

The captions and photographs below that appeared in the Times on December, 2015 clearly shows the comedy of errors and made South Africa the laughing stock of the world under the Machiavellian President Jacob Zuma:
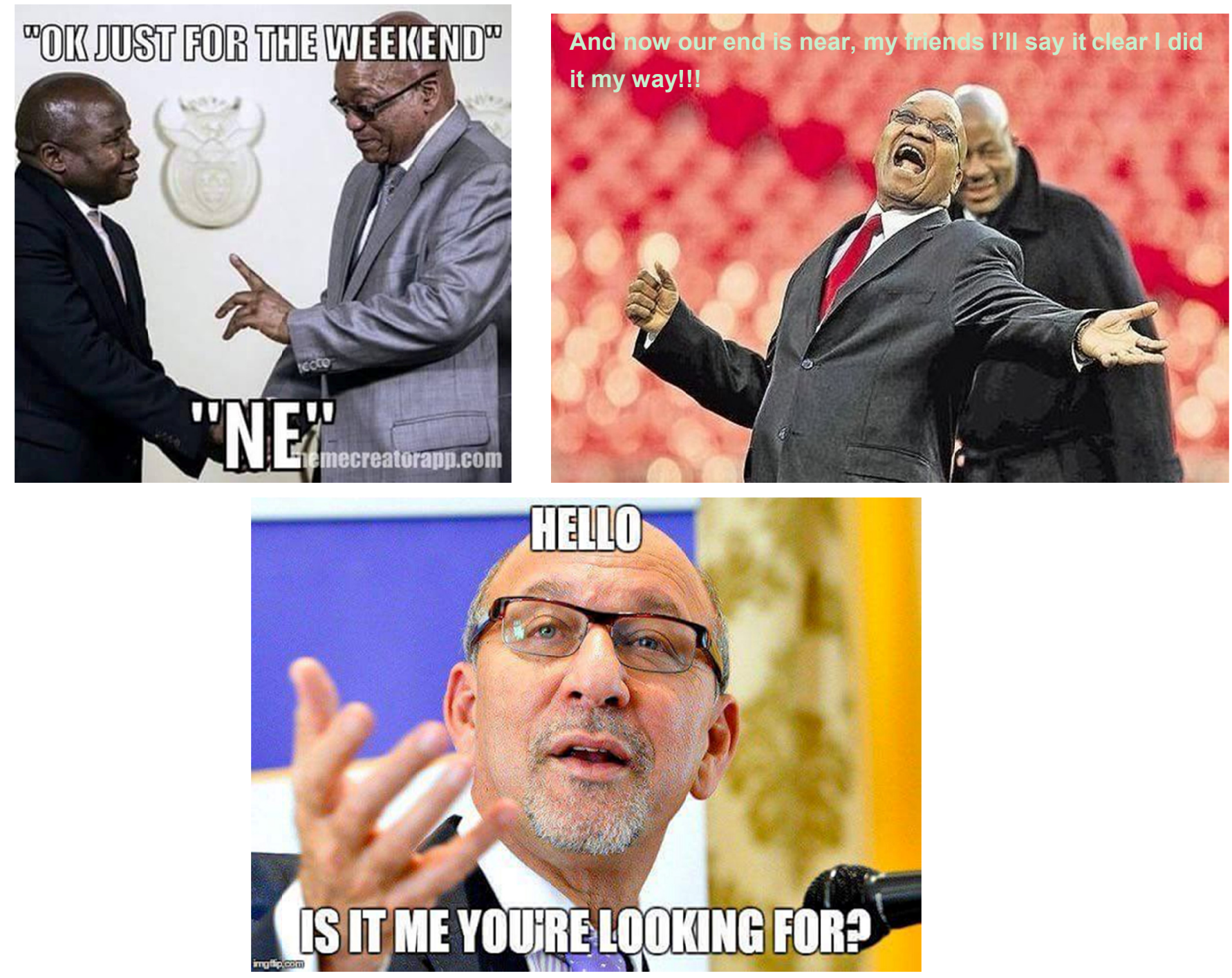
The 4 day Minister of finance Van Rooyen President Zuma the Laughing Stock

Above South Africa's competent and longest serving Minister of Finance Trevor Manuel

Sources: Twitter and the Times, December 15, 2015.

\subsubsection{Van Rooyen was a 'Miscalculation' According to Reappointed Minister of Finance Pravin Gordhan}

Reappointed Finance Minister Pravin Gordhan has admitted that giving David van Rooyen the job was a miscalculation. There are times when you have to admit that there was a miscalculation and the need for the review of the decision and the need to move on to a new scenario Gordhan said" according to Masombuka (2015) "The sacking of Nene shook the markets and put the Rand into a nose-dive. Gordhan said that "he would move swiftly to stabilize South African Airways (SAA) and that governance was non-negotiable. We cannot avoid the necessity of wide - ranging reforms. Investors must be reassured that there would be no fiscal policy shift and that the government was aware of the effect of Zuma's flip - flopping on the economy. He further emphasized that curbing spending was sacrosanct and averred that the only way to have extra expenditure was to raise extra revenue" (Masombuka, 2015). By appointing David van Rooyen as Minister of Cooperative Governance and Traditional Affairs, Zuma has damaged the ANCs election prospects next year. Mahlangu and Dlamini (2015) state that "according to ANC insiders van Rooyen would not last long in this portfolio because they believe that he is not the right person for the job. It is a disaster that will impact on the ANC and removing him will give us space."

However, it must be remembered that by appointing Pravin Gordhan as Minister of Finance brought back some sanity to the markets, but the damage has already been done, as South Africa reels and goes further into the abyss and doldrums of a tarnished economy. Gordhan assumes office at a time when the ANC is preparing for local elections in 2016 and, will have to sing the tune of the ANC and allow the government to spend as it likes, in order to win the local elections. The ANC is being threatened by losing some of the large metropolitan municipalities because of its poor track record, in respect of service delivery, rampant corruption, it's propensity to spend without any accountability and to ignore Treasury instructions. By the same token, it must be remembered that Gordhan might be an astute Finance Minister, but has to please his political masters and to this end, he too will not be in a position to steady the faltering and sliding South African economy. It must also be recalled that it was under Gordhan's watch that public servants salaries increased and escalated to nearly 60 percent of GDP and that he had sanctioned the unnecessary spend of over R256 million on the controversial Presidential homestead in Nkandla. In other words, he has to be a "yes - man" Minister of Finance or he too will have to bear the brunt of the ANC. South Africa is in a no win situation under the Machiavellian President and his politically appointed cronies on the basis of patronage.

\subsubsection{Gordhan's Mettle Will be Tested}

The still - nervous markets are watching closely to see how Gordhan deals with several critical issues. These are some of the Issues that the reappointed Gordhan will have to contend with as Minister of Finance:

$>$ It remains to be seen whether Gordhan will be able to achieve what Nene was trying to when he was unceremoniously fired.

$>$ Can he or will he be in a position to stop the propensity of spending by government, the SAA debacle, the affordability of government's nuclear programme, the funding of the higher education scenarios, the electricity crisis, coupled with the water fiasco that requires billions of Rands to rectify, the implementation of the controversial and costly National Health Insurance plan (NHI), that will run into trillions of Rands, curbing public servant salaries, financing the 2016 local government elections and so on, particularly, at a time when South Africa has no money and would have to borrow more and more money to service its growing debt and to provide social services to a restless and demanding public.

$>$ He also has to deal with the controversy surrounding the alleged operations of an investigative unit in the South African Revenue Service (SARS) in which he is implicated.

$>$ Will he be in a position to home in on loss making state - owned entities?

$>$ Gordhan as the previous Minister of Finance was unable to neither stop large government spending on luxury issues such as cars, the use of alcohol in large amounts at government functions nor cut the outrageous amounts of money used for meals by government and its public servants, or for that matter curb the exorbitant costs for large delegations that go abroad constantly and many other issues that he mooted which were ignored and paid scant reference to by his Cabinet colleagues. (These measures were once again placed on the table by the President in his 2016 State of the Nation Address (SONA). Experience indicates that nothing will be achieved in terms of this cost - cutting measures. It is more of the same).

$>$ The issue is would he be a pliant or compliant Minister of Finance? It points to the fact that he will be a compliant Minister of Finance to a Machiavellian President, who has reappointed him and, the fact that he has no 
constituency within the ANC and, has to toe the line or bear the wrath of the President and the ANC and, the labour unions and, indeed the alliance partners of the ANC.

$>$ In addition, a host of other issues will have to be taken into consideration by him as finance minister, if he has to survive. This will do the country no good.

\subsubsection{Gordhan no Horatius on Bridge - South Africa Firmly on the Path to Bankruptcy}

R. W. Johnson (2015: $1-8)$ in his article summarizes as follows given the Herculean and Machiavellian decision to fire Finance Minister Nene.

$>$ "The country continues along its path to bankruptcy and asks as to how long will South Africa last?

$>$ In this regard he states that "Zuma revealed him - self again, to be little more than a semi - educated street corner activist. Unfortunately, a rather expensive one for taxpayers.

$>$ The best comment came from the EFF'S Julius Malema who said that "The situation was one of a "pathological crisis" and that no one in the world will trust a political leadership that changes Cabinet and finance ministers like underwear" (In Johnson, 2015).

$>$ The shock created by Nene's eviction was profound and the only politician who grabbed the chance was the Minister of Health who had been instructed to get together with the Treasury to present a joint White Paper on National Health Insurance. The Treasury, knowing full well that NHI was an unaffordable dream.

$>$ The Minister of Health's announcement was laughable because, it was a plan based on the happy dreamland of a steady GDP growth rate of 3.5 percent, which is now unachievable for a long time to come.

$>$ The General Secretary of the ANC who was tight lipped as the saga of the sacking of Nene unfolded, was furious at the damage already done. The General Secretary together with others in the top six within the ANC executive had clearly let Machiavellian Zuma know of their strong displeasure.

$>$ Ironically, these places Gordhan, who was a weak finance minister (for many reasons) in 2009 - 2014, in a position of great strength, but it will certainly be wrong to imagine that he will play the role of the Iron Chancellor, the Horatius who holds the bridge. It is all a bit too late and the antics of the sacking of Nene certainly implies a recession in 2016 and that will make a further downgrade extremely hard to avoid.

$>$ Historically under the Zuma Presidency there is a complete unwillingness of the ANC government to insist on financial discipline in all sectors of government.

$>$ Even after PetroSA incurred losses of over R14 billion in a year, it was not allowed to go bust. The large promises made for vast and unaffordable new spending on NHI, nuclear power stations, the electricity and water crisis and the problems of funding higher education are very serious issues. These issues run into trillions of Rands and, South Africa just does not have the money because of the mismanagement of the economy.

$>$ New pressures were not factored into the equation such as free higher education. It is therefore, unimaginable that the government and the new Finance Minister will be in a position to hold the line and, if a finance minister really tried to do this in a fractured and toxic political landscape, he would be sacked (Emphasis added).

$>$ Why is this so? There are three reasons (1). That the economy has been so lamentably mismanaged that there is a tendency to let public spending take the consequent strain, through new investment projects, more pensions, more grants and even down to creating large numbers of jobs. But the key point is that the ANC state relies completely on patronage networks and on private looting. What this means is that that there is always more pressure to find new means of patronage. Thus - these new initiatives will carry with them opportunities for extensive private gain. Both of these two factors require public spending to keep inching up. (2). All of this points to the reality that South Africa is very poorly governed, full of paranoia and imaginings by a government completely out of kilter and obsessed with looting and wanting to stay in power at all costs because of its fundamentalist assertions. (3). Lastly, in the midst of this meandering performance the Machiavellian President revealed that he did not accept that value was dictated by the laws of supply and demand; instead he was an adherent of the labour theory of value which even Marxist economists stopped defending by the 1960's.

$>$ Zuma's hasty denial that he had had another love - child with the Chairperson of SAA Dudu Myeni, (Responsible for the firing of Nene and many others previously) merely drew attention to the fact that he had put the country's economy at risk in order to placate one of his girlfriend's probably not even realizing that he was doing so.

$>$ To put it mildly, the markets have been deeply shocked to see that a G20 country like South Africa could be governed in such Ruritanian fashion and many investors were made to feel that they had dramatically under assessed the country's political risks. That is why South Africa was already paying 8.6 percent on its debt until Nene's sacking took this figure to 10.4 percent.

$>$ This in turn is bound to create pressures for cuts in public spending, always an extremely tough task for any finance minister in a situation of low or no growth and high unemployment. But what makes it all so much harder is the complete lack of economic education among ANC MP's and ministers. 
$>$ It must be remembered and the world economic development scenario clearly shows that an all - out attack on inequality without any consideration for the fact that redistributive policies quite normally throttle growth. Others advocate a high minimum wage (Advocated by Cosatu the ANC's alliance partner) with no concern for the higher unemployment this would cause. There are also advocates in South Africa that press for higher taxes in a country reeling with an economic crisis to fund the NHI and other programmes, which can be termed Scandinavian delights.

$>$ No one in South Africa, particularly the naïve South African government, who recently invited the French economist Picketty to address the Cabinet and who advocated a wealth tax in a country with a very small tax base. When President Mitterrand attempted to introduce such a tax in Picketty's native country France, it quickly became a laughing stock, raised only a miniscule amount and had soon to be scrapped.

$>$ All of this shows that under the current Machiavellian President and the ruling ANC elite considerably harsher contours of South Africa's real situation are made plain to all citizens" (Note: Emphasis was added in this part of the narrative by the authors).

\subsubsection{Zuma's Blunder Gives South Africa the Chance to Cross its New Rubicon}

Zuma and his political cronies have become a law unto themselves. The Machiavellian President has held the country at hostage and is recklessness personified as he believes that South Africa is his personal toy. Analysis reveals that he is moonlighting as president. His real interest lies elsewhere, with himself, his family, his cronies and his party, in that order. In firing the capable Minister of Finance Nene, Zuma's reckless decision is unprecedented in post - apartheid South Africa. Hopefully this blunder will expedite Zuma's departure and South Africa would then have had rid itself of a Machiavellian character. He is now by far the single biggest threat to the future of this country. He believes that with his political cronies at his side, he is untouchable or for that matter infallible. Barney Mthombothi (2015) states that "what is frightening is that Zuma seems totally oblivious to the utter stupidity of his action. He does not seem to know or care about the havoc he's wreaking. It boggles the mind that former President Mbeki was fired and recalled by Zuma supporters within the ANC, for what amounted to a little more than a personal grievance, yet the ANC is incapable of reigning in this destructive force, it has let loose on the land and its people. It either gets rid of Zuma, or the rot will turn people against the ANC. Their judgment could be severe."

How did South Africa allow itself, in little over two decades to end up in this quagmire? It is simple they got rid of Thabo Mbeki, disbanded the Scorpions the efficient bulwark for corruption and thus opened the sluicegates to rampant corruption under the leadership of the Machiavellian President Jacob Zuma. As Mthombothi (2015: 21) points out that "of the original triumvirate that paved Zuma's path to power, Zwelinzima Vavi the former Secretary General of Cosatu and Julius Malema now the leader of the opposition Economic Freedom Fighters (EFF) are both out. Blade Nzimande the current Minister of Higher Education and the leader of the South African Communist Party (SACP), there is no doubt that, he is on the way out given the debacle of the \#FeesMustFall protests. (What are they waiting for (the Cabinet)? He must go now or higher education will be destroyed and by the same token the Zuma crony, the Minister of Basic Education (Angie Motshega) must also be relieved of her duties because, of her consistently lackluster performance. They are both a threat to the total South African education landscape after 21 years of mismanagement. His star (Minister of Higher Education) has waned because of his arrogance and that many in the ANC have lost hope in him as the Minister of Higher Education. He will soon join them in the wilderness as things unfold in 2016 and, so will the Minister of Basic Education). All of them thought that the Machiavellian President Jacob Zuma was a giggling, malleable simpleton who could be used. They miscalculated very seriously. A man without principles has neither friends nor enemies. The Machiavellian Jacob Zuma is a consummate chameleon, without a backbone to boot." These are precarious times, but it is also an opportune moment for those waiting in the wings to grasp the nettle. As Mthombothi says (2015) "Waiting for Zuma to shuffle off into the sunset could be cowardly, or take too long. Take the bull by the horns now and point the country in a different direction."

Some ANC leaders believe bosses manipulated global markets in order to topple the president and say that he us under siege by capitalists who are colluding with anti - Zuma campaigners within the party (Mail and Guardia, 2015). This is hogwash and the manner that the ANC reacts when its back is against the wall. In this regard Small Business Minister, and past advisor to the President has come out with guns blazing in defense of Jacob Zuma. In spite of this unreasonable support for the President, the Mail and Guardian (2015) states that "The ANC was forced to put pressure on Zuma to reconsider his decision and, therefore, the reappointment of Pravin Gordhan as Minister of Finance was because, warning bells rang that investors were pulling out of the country and, that, the situation was likely to get worse if government did not intervene decisively. Zuma's apparent failure to consult alienated the Secretary General of the ANC and Deputy President Ramaphosa. Bankers within the country's major banks put pressure upon the presidency and the ANC which saw the president reversing his decision. All of this has split the ANC in spite of the fact that, it is in denial mode given this fiasco. A government insider indicated that Ramaphosa felt frustrated as the Secretary General of the 
ANC about relationships with Zuma. Ramaphosa the Deputy President was suffering to get a meeting with President Jacob Zuma for the last seven months. Ramaphosa is the candidate to succeed the Machiavellian President.” Not all is right in the state of South Africa as it goes from one controversy to another under a Machiavellian President.

\subsubsection{Economic Apocalypse Averted}

South African came terrifyingly close to a meltdown, and nervousness remains. The South African economy was gazing into an abyss and was pushed over the edge by President Zuma when he removed the Finance Minister Nene. According to Lisa Steyn (2015: 1) "In the worst case scenario, the currency could have continued to weaken, potentially past R20 to the dollar. Inflation would have rapidly escalated, forcing the Reserve Bank to hike interest rates aggressively, which would have further slowed economic growth, resultant credit rating downgrades and high bond yields, coupled with large capital outflows, would have made the cost of government funding unsustainable." Under the circumstances, the country may have had to turn to the International Monetary Fund (IMF) for a bailout. The stock market according to the press and Lisa Steyn (2015) "Lost R230 billion in values and the bond market R217 billion, equal between 10 to 15 percent of the economy. The loss of R437 billion wiped out the equivalent of two year's worth of economic growth from South Africa's savings pool." The fear that would have gripped South Africa would have been hyper - inflation in the long term. The prioritization of political issues over reforms put South Africa firmly on the path to junk status. It is now very possible that in spite of Gordhan's appointment the South African economy will be downgraded to junk status in 2016 (Watch the announcements that will be made by the Finance Minister in his February, 2016 budget. After the Finance Minister's budget is tabled on the $24^{\text {th }}$ of February, 2016, the authors will prepare a new research article to outline the Minister's intervention strategies and to see as to how the ratings agencies receive his budget).

This will force investors to leave and would take the Rand on a very rapid trajectory to even above 20 Rands to the dollar. (Which has already happened?) There is no doubt that the Machiavellian President overplayed his hand and underestimated the reaction of the markets because, it will also take the government's funding and debt servicing costs, already a concern for rating agencies to unsustainable levels, meaning that its infrastructure programme, the core of its economic programme, would have to be curtailed drastically.

The budget is under stress. Montalto (In Lisa Steyn (2015) states that "Higher bond yields would have increased the cost of borrowing by more than R5 billion a year and that government would have had to take that from spending plans every year from now on. It might not be a very long walk to the IMF. The bond yield would have to be around 15 percent for the IMF to come in. That's 50 percent above a junk bond yield. It is obvious in economic terms that that you get to the IMF when you start getting failed auctions domestically, so you do not have sufficient resources to import what you need." (Failed auctions mean more of a shock outflow and a sudden stop in the balance of payments). What Zuma does not understand is basic economics because the hardest hit in a doomsday scenario would have been the poor. Gordhan's appointment has reversed some of the damage, but certainly not all. All of this would definitely lead to interest rate hikes and this would probably happen in January and March of 2016. South Africans were hoping for a R9 or R10 to the dollar and now this is not going to happen. Higher bond yields might mean the government will have to issue more debt to meet the borrowing requirement, which would result in higher debt - service costs.

The biggest impact is that trust has been broken because of the decisions of the Machiavellian President who is out of depth in understanding the economy and the crisis that he has put the country into. This leads to higher risk premiums on South Africa's global bonds. Let's be frank the President has put South Africa on the back foot and magnifies concerns about South Africa's Achilles heel. There can be no normality in the short term and, the new Minister of Finance Pravin Gordhan would not be in a position to reverse the damaging scenarios in the short to medium term. The two graphs hereunder show how South Africa almost became a zombie economy: 
How South Africa Almost Became a Zombie Economy

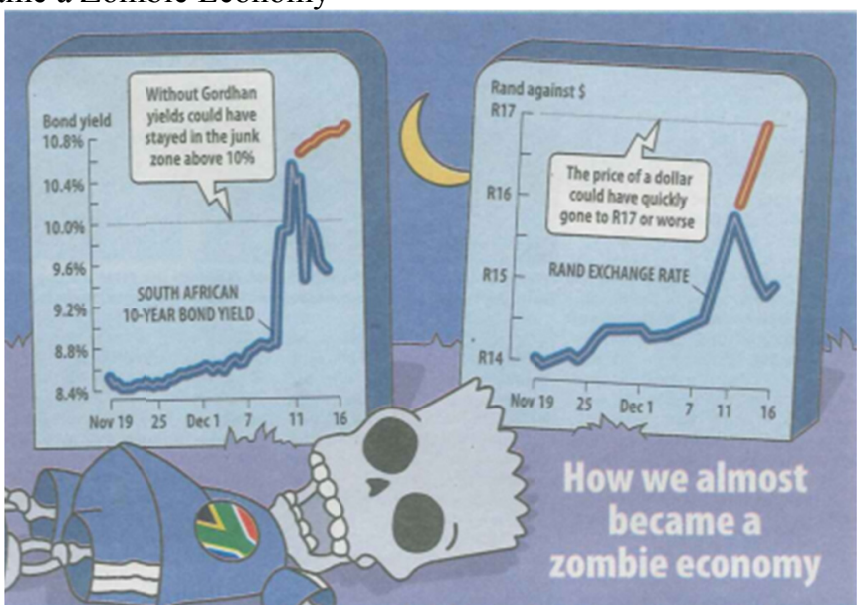

Sources: Bloomberg and the Mail and Guardian, December 18 to 22. Business.

\subsubsection{There are Limits to the State Presidents Power}

The year was one of disastrous and shameful decisions. The odds on Machiavellian Zuma's surviving 2015 were just above 50 percent; now they are significantly below that mark. Politically, 2015 was a year of drama, paranoia and grotesque misjudgments according to Richard Calland (2015: 21). He sums this up as follows:

$>$ "It began with the EFFs Julius Malema's appalling attempt to disrupt the State of the Nation Address (Sona) and the shockingly violent nature of how Malema and his EFF MPs were removed from the National Assembly by specially trained police officers masquerading as parliamentary security officials. This tarnished the reputation of the ANC led government and tarnished true democracy.

$>$ The grotesque misjudgment of the minister of intelligence in blocking the cellphone signal in and around Parliament. This was denied by the Minister and the ANC and, its government. It was later proven to be true.

$>$ The above decision exposed weakness, not strength in government and in the ruling party, a persistent theme of the political year, under the ANC led government.

$>$ Battered by an uncongenial global economy and unable to make much progress in escaping the clutches of the stubborn structural constraints embedded in the domestic economy, ANC leaders in government lashed out at softer targets more readily, such as the judiciary and intimidated them. The Minister of Justice and the Secretary General of the ANC had gone public with complaints against former judges being associated with litigating nongovernmental organizations and ruling against the government consistently.

$>$ The ANC and the government lashed out at the Public Protector because of her attack on the President and the funding debacle of his homestead at a cost of R256 million, which in the main was misappropriated and defended by the Minister of Police and other high ranking Ministers and bureaucrats. The Public Protector was denied a budget to carry out her duties and humiliated in Parliament. She was forced to close a number of Public Protector regional offices throughout the country. Technically, the office of the Public Protector is being emasculated by the ANC government which is a tremendous blow to South African democracy.

$>$ In reality opposition parties were much more effective this year at using the National Legislature as a place to test ANC hegemony and poke holes in its defenses.

$>$ There was a large untapped political activism and vigour apparent in the student protest of \#FeesMustFall that, forced government to make a $\mathrm{U}$ - turn on fee increases in Higher Education for 2016.

$>$ The opposition Democratic Alliance (DA) elected its first black leader this year.

$>$ In respect of the Nkandla debacle the ANC (Presidents homestead) dismissed the ad hoc committee when the ANC used its majority to unconstitutionally evade presidential accountability arising from the Public Protectors findings on unlawful public expenditure.

$>$ What the ANC has not realized is that their actions have allowed the rise of Malema's dangerous populism.

$>$ We saw the infighting within the ANC alliance partners and, the split of Cosatu and, we saw that Cosatu and the SACP leadership were able to exercise decisive influence at the top of government. 
$>$ It was left to Deputy President Ramaphosa to intervene to stop the cell phone signal blocking in Parliament and, other ANC alliance leaders who told Zuma to stop his extraordinarily reckless decision to fire Nene and then appoint a backbencher and novice to the most important Cabinet position of Finance Minister.

$>$ The message was clear to the Machiavellian President in respect to his power and that he was crossing a line and this was a grotesque misjudgment on his part attempting to take all of his Cabinet, the ANC and the people of South Africa for granted. He is severely, perhaps fatally, damaged as a result."

Machiavellian Jacob Zuma ends 2015 far weaker politically than when it began. The National Treasury remains bruised. The issue at hand is to ask, if democracy is alive in South Africa under Zuma or perhaps, it is the time that he departs from the political landscape of South Africa. South Africa cannot afford to keep a Machiavellian at the helm of its political and economic agenda, if it wants to regain lost ground and, set the country once again on a trajectory of sound development, avoid junk status and usher in the much needed confidence of international investors and, turn around the battered domestic economy, thus giving citizens much needed hope in a very depressing country.

\subsubsection{Former Finance Minister Trevor Manuel Speaks out Against Small Business Minister Lindiwe Zulu}

Given the fiasco that followed the dismissal of Finance Minister Nene, which saw South Africa's economy spiral downward and into oblivion, the respected and astute politician and, high ranking member of the ANC Trevor Manuel, the former and longest serving Finance Minister in post - apartheid South Africa (2015) said that "It cannot be correct that there is an outside hand (and not the ruling party) that knows more than the Cabinet does about unfolding events. (He said in an open letter to Small Business Minister Lindiwe Zulu, a staunch supporter of the Machiavellian President Jacob Zuma, who accused outside forces and big business that was bent on removing Zuma) which was published in the City Press, in the latter part of December, 2015 that "From what, I have heard, the removal of Nene from his position as Minister of Finance and as a Cabinet Minister, came as a complete shock and that, at a Cabinet meeting on December $9^{\text {th }}$ no mention was made of the impending removal of Nene." Two days after the sacking of Nene the Minister in the Presidency Jeff Radebe told reporters that the Cabinet had been in the dark about the sacking. Mr. Manuel further added that "The dismissal of Nene shook the trust of the Cabinet collective at its roots and the saga of dismissing a competent minister and replacing him without warning or explanation led to a complete breakdown in trust and that this trust was also broken within the ANC" The breach of trust was the last straw that broke the camel's back in the careless handling of the important finance portfolio. He said that "It was strange that the childhood friend of van Rooyen, (a Mr. Rabotapi) the newly appointed Minister (for 4 days only), told the press that he had known about the appointment months ago. Manuel asked and pointed out "how is it possible that when van Rooyen arrived after being appointed as Minister of Finance, he arrived at the Treasury with two advisors. How did he acquire their services even before he had been sworn in as Minister? As such, subsequent attempts by various people in the ANC to justify van Rooyen's appointment as that of a rising star fall flat, and consequently, the issue of contention and disbelief was never about having van Rooyen, it was about the summary dismissal of Nene, a thoroughly decent, smart, diligent and more than capable individual and Minister of Finance."

The veteran ANC comrade and wife (Barbra Hogan) of struggle hero and Robben Island prisoner Ahmed Kathrada, (the closest friend of Nelson Mandela, who spent 26 years in Robbin Island Prison), served as Minister of Health and also of Public Enterprises (Barbra Hogan) was also removed from her ministerial positions for criticizing the ANC and has called on the party's members to speak out against the decision to fire Nene. She said (2015) (In Manuel, 2015) that "If ANC members are worth their salt, they have to start looking very carefully and introspectively at our roles in this organization and what we are giving consent to by allowing this president to operate though he is completely unaccountable." Trevor Manuel criticized Minister Lindiwe Zulu for what he called the reckless comments she had made to the Mail and Guardian newspaper in December and long after the sacking of Finance Minister Nene, in which she blamed business for its lack of support for Zuma and the economic fallout. As usual she said that she had been quoted out of context. Manuel counteracted, suggesting that Zulu was plainly wrong in her assumptions about the roles, responsibilities and attitudes of business. He said (2015) that "The path forward was to repair the trust, the legitimacy and, if you must, the obedience of the governed." After stringent attacks by a host of individuals and the press Minister Lindiwe Zulu retracted her comments over the big business plot to overthrow Zuma. It must be realized by the ANC that the Machiavellian President, a complete dictator is now a damaged man, running a damaged country because of his political and economic shenanigans but remains unfazed as he forges ahead with the support of the ANC that has lost its way and has compromised itself as the vanguard of the revolution. The South African economic crisis is a reflection of the downturn among numerous emerging states which have experienced substantial growth over the last decade. A decline in commodity prices, including oil and other natural resources, has illustrated the continuing dependency on the existing capitalist dominance of the world system. A system that that the Machiavellian President seems to ignore to the peril of South Africa and its people. 


\subsubsection{Named: Van Rooyen's Two Gupta “Advisors” Who Almost Hijacked the South African Treasury}

The foregoing discussion by Alec Hogg from Africa Confidential (2016) outlines the fiasco of the firing of Finance Minister Nene. It also alludes to the influence of the Gupta family on President Zuma because of their business influence and, as to how they as an immigrant family have high jacked the South African economy in partnership with the president, his family and his political cronies. To this end there is a hue and cry by the Economic Freedom Fighters led by Julius Malema that the Gupta family must leave South Africa for good. To this end the ANC has attacked the EFF for its stance on the expulsion of the Gupta family from South African soil.

Alec Hogg ( 2016) points out and writes that "The day after the shock of respected Finance Minister Nene being replaced, David van Rooyen the new Finance Minister arrived at the South African National Treasury with his two until now named "advisors." In his article Alec Hogg republished with permission from the London-based Africa Confidential names the duo as "Gupta allies" Mohamed Bobat and Ian Whitley and explains the context in graphic detail. Their arrival so shook the Treasury that its Director General threatened to resign and his staff immediately dubbed the event " $9 / 11$ " - a reference to the US's disastrous " $9 / 11$ " in 2001 . The discussion below is the fascinating inside story from Africa Confidential, the subscription-only service which have been covering the continent for more than half a century (Alec Hogg, 2016).

"Delivering the State of the Nation address at the opening of what promises to be South African Parliament's most turbulent year, President Zuma announced a series of measures to shore up the country's ailing economy, including cutting government expenditure, revamping the management of state-owned enterprises and partnering with the private sector to promote domestic and foreign investment. The measures are high on the wish list of a formerly disengaged business community which was shocked into action by Zuma's disastrous sacking of Nene and the crash in share prices and the value of the rand that followed. The dismissal of Nene turned out to be the latest in a series of cabinet appointments made to circumvent resistance to the deal Zuma struck with Russia's President Vladimir Putin last year to build nuclear power plants in South Africa (This confirms the assertions made by the authors elsewhere in the narrative). Successive Ministers of Finance and of Energy who voiced their opposition to the deal over its enormous costs were removed from office. The main beneficiaries of the nuclear deal would have included the controversial and influential Gupta family - three Indian brothers who have become massive beneficiaries of Zuma's patronage. (It must be placed on record by the authors that that this Indian family the Gupta's are new immigrants to South Africa, from India and, must not be confused with South African Indian settlers who settled in South Africa over 150 years ago as indentured labourers and traders and, were brought to South Africa by British colonialism to develop and work the sugar industry. They, the Gupta's, who are naturalized South African citizens and, complete nonentities in India, prior to their settling in South Africa, do the South African Indian population a great disservice. A South African Indian community that played a magnificent role in the liberation struggle of South Africa from the yoke of apartheid oppression and, have contributed more than magnificently to South Africa, in all walks of life. The Gupta's influenced Zuma to appoint the previously unknown David van Rooyen as Finance Minister, it is now generally accepted. The intention was to secure uranium contracts for the nuclear plants in the same way they have for the coal and arms sector, according to the local press.

"Another part of the strategy was to place two Gupta allies, whom Africa Confidential has named (See Above). Whitley is a former head of small and medium enterprises at the defunct African Bank. When van Rooyen was replaced at the Treasury, the two men went with him to his new portfolio of Local Government and Traditional Affairs, and appeared with him when he was sworn in on 10 December, 2015. Alec Hogg (2016) reports that Ian Whitley was "A matriculant and, spent 14 years at Standard Bank and 5 years at ABSA Bank as a mid - level banker. His last two years in the sector was at African Bank which he left last May by mutual agreement. In his LinkedIn profile, job - seeking Whitley tells prospective employers he is willing to pursue a postgraduate business diploma _ _ provided this adds more value to the organization's needs. A former colleague at African Bank burst out laughing when told Whitley is now a well-paid advisor to a weekend special Minister of Finance David van Rooyen. Africa Confidential (In Alec Hogg, 2016) says that Whitley qualifies because he is a Gupta ally. That's one of the few things that make sense in the whole sorry Nenegate saga. Because, surely, his sudden elevation wouldn't have anything to do with his being married to a daughter of ANC top six member Jessie Duarte, who is also the Deputy Secretary General of the ANC." This is political patronage and corruption of the highest level in a country that has lost its way completely under President Jacob Zuma and, his Machiavellian tendencies. Bobat and Whitley, who have associations with the Gupta's and their businesses, visited the Treasury before van Rooyen's appointment and told officials that they would be able to sign expenditure and other authorizations on behalf of the new minister but otherwise there would be no changes. Senior Treasury officials led by Director General Lungisa Fuzile was appalled that they threatened to resign unless van Rooyen's appointment was reversed. The requisite skills of both Bobat and Whitley were questioned by the Treasury. Following the firing of Nene in December, it was business leaders acting in concert with moderates in the African National Congress who forced 
Zuma at political gunpoint to reverse his appointment of a stooge as finance minister and re - instate the highly respected Pravin Gordhan. Further details have now emerged about the meetings in which Zuma fought tooth and nail not to give in. At one of them Patrice Motsepe, the billionaire benefactor of the governing party, told Zuma to be quiet and listen to the business leaders. Zuma's former wife Nkosazana Dlamini - Zuma, the main rival to Cyril Ramaphosa and, supported by President Zuma in the succession stakes, expressed shock that the President could be addressed in such a way."

Intense and high - level meetings between government and business followed in rapid succession at the World Economic Forum in Davos, Switzerland, in January. There was a follow - up meeting between Gordhan and Zuma and 60 captains of industry and finance on the 29 January. Zuma met over 100 business chief executive officers on $10^{\text {th }}$ February in Cape Town on the eve of the State of the Nation speech. At this meeting hosted by Old Mutual /Nedbank and chaired by Gordhan, emergency working groups were set up to report within four days to: promote economic growth, take steps to stimulate foreign and local investment, revamp the management of state - owned enterprises, and take urgent steps to avoid junk status for investment. Gordhan and his officials then processed the recommendations in record time and, they were fed in as the core content of Zuma's State of The Nation speech. It was the best coordinated collaboration between government and business in 22 years of democracy, insiders said. The dramatic sequence of events has put Gordhan in the driving seat of government and all but indemnified him against dismissal.

At the mining indaba in Cape Town in the days before the State of the Nation speech, Zuma would have felt additional pressure from mining luminaries who shared the views of the CEO's who were directly in touch with the President, such as Simanye's Neal Froneman, Pallinghurst's Brian Gilbertson, Adam Fleming, Clifford Elphick of Gem Diamonds, Africa Invest's Rob Hersov, hedge fund manager Julian Schrager, Lord Robin Renwick of Hannam and Partners and Ivanhoe's Robert Friedland. Global players who also added to the pressure on Zuma included Indian steel tycoon Lakshmi Mittal, who was contemplating a major investment when news of Nene's dismissal broke. President Xi Jinping of China is also understood to have, delivered a message via diplomatic backchannels to protect China's 20 percent stake in Standard Bank. The country's two richest families - the Oppenheimers (Nicky and his son Jonathan) who recently sold the diamond giant De Beers to the ailing Anglo American, and the Ruperts (Johan) who command a huge international empire, kept a low profile through the affair. The events also revealed that the two more recent plutocratic dynasties, the Motsepe's and the Gupta's, are increasingly at daggers drawn as they vie for influence over the ANC.

Deputy President Cyril Ramaphosa is backed for the succession by the Motsepe's. He is married to Patrice Motsepe's sister Tshepo but is trailing Zuma's former wife, in the succession stakes. She is backed by her former husband and the Gupta's. Motsepe's other sister, Bridgette, a billionaire in her own right, is married to Minister in the Presidency Jeff Radebe, a Ramaphosa ally. (This is the sordid state of politics in South Africa. Too many of them are in office for far too long and, wield uncontrollable political and economic influence, and hide behind their long expired revolutionary credentials. It's time that they all leave the South African political landscape with President Zuma and allow young South African leaders to emerge or else there will be no change). At the shambolic opening of Parliament, the Economic Freedom Fighters walked out of Parliament in their signature red overalls chanting "Zupta must fall"-a cryptic reference to the Gupta family and Zuma. Mosiuoa Lekota, Leader of the Congress of the People, an earlier breakaway from the ANC, was the first to lead his party in a parliamentary walk - out proclaiming that he was not prepared to listen to a man who had violated the constitution and was unfit to lead the country. He became a hero for his stance.

On the eve of the opening of Parliament, the two main opposition parties which stand to take votes from the ANC in the coming local government poll-probably on 3 August, brought charges against Zuma in the country's highest court for violation of the constitution. The Democratic alliance and Julius Malema's EFF joined forces to have the President declared unfit for office over his refusal to abide by the Public Protector's binding ruling that he should reimburse the state for the multi - million upgrades to his retirement compound. A finding against the President would create a constitutional crisis as Parliament, in which the ANC has a clear majority, would be in conflict with the Constitutional Court, which is the supreme constitutional authority. If the ruling goes against the President, it would be grounds for his impeachment. There are also grounds on the basis that he breached his oath of office, by constantly lying to the country about his role in the use of taxpayers' money in the financing of his Nkandla homestead."

The above expose clearly shows that the President of South Africa has displayed Machiavellian tendencies and, it's is now time that he exits the political landscape of South Africa for good. He has harmed the country immensely. "On the other side of the continuum, the State of the Nation Address was graced by politicians with glitz and glamour, out in their Sunday best costing thousands of Rands, in state of the art fashion with their spouses and partners, amidst a country that is in turmoil economically, is bleeding and, to cap it all, its people the black majority who are poor are living in increasing poverty, extremes of inequality and along with very high unemployment. This show of decadence and hedonistic behaviour was a slap in the face of poverty as the red carpet was unnecessarily rolled-out (Mhlungu, 2016, Mbele, 2016). "It is time to tighten the belt not if it is Louis Vuitton, as the rich continue to spend like there is no 
tomorrow, amidst a sea of extreme poverty" (Govender, 2016). This reinforces the notion of an uncaring state and its uncaring politicians and, the uncaring elite and the uncaring rich.

\subsubsection{Zuma Must Fall-Hold the Racism}

The nation rose up against the dictatorial and Machiavellian President Jacob Zuma and forced him to change his mind about dumping a highly respected finance minister and replacing him with a political nonentity who would, obviously, lack the strength to block deals that might compromise fiscal probity or alternatively, the ANC's mandarins got a big shock when Zuma dumped Nhlanhla Nene, so they quickly assembled to confront him about it and made him backtrack. Or they did 'so, semi-independently, but with the support of the big bankers and mega business people who could explain authoritatively to the president how his unilateral action had slashed billions of Rands in value off the banking share index and sent the Rand into free-fall. Or, yet again, if we follow the message put out by the ANC that Zuma took the weekend and having thought very carefully, saw the best thing to do was to put a former finance minister in that position, in order to calm everyone down" (Mail and Guardian, Editorial, 2015).

In reality, it was probably a combination of all of the above accepting perhaps what was proposed by the Deputy Secretary General of the ANC Jessie Duarte. She did not convince because few observers are ready to believe the president gave thoughtful consideration to the broader effects of his decision to dump Nene in the first place, or can imagine that someone who is clearly financially challenged himself is able to compute the likely effects of such a decision. That and the fact that it's difficult generally to believe what Duarte says in matters like these because she is so blatantly a party hack. As writer Tom Eaton (In Mail and Guardian Editorial, 2015) noted online, "It was as though Zuma shot South Africa in the foot and then the ANC called a press conference to tell us how neat the hole was." But the ANC mandarins and the money guys did give Zuma a little talking - to. The nation did rise up, at least that part of the nation who know what a ratings downgrade is, who know what it means if your interest payments rise dramatically, or if you have to pay for large amounts of imported maize in Rands worth so much less than they were a week ago. That means, increasingly, as South Africa's economy clings to the cliff edge, more and more South Africans learn this stuff every day, and as it does so does with anger, at how Machiavellian and dictatorial Jacob Zuma was willing to cut the economy off at the knees without even giving an explanation.

These South Africans tweeted; Face booked and gathered in places like Nelson Mandela Bridge and marched across cities. Unfortunately, they looked mostly white, and some of the comments attached to the \#ZumaMustFall tag were downright racist" (Mail and Guardian, Editorial, 2015). This enabled government spokespeople to tweet that such protests, as a whole were anti - majoritarian. This will be a key part of the ANC's defense of Zuma in the near future, that and the notion that any protest is anti-ANC. Party ideologues will try to make the protests look as though they are being driven by privileged whites who do not want to give up their riches. Those making a serious protest need to make sure they stick to the issue that the movement is not hijacked by racists, and that the groundswell against corruption and unaccountability keeps growing. The time has come for all South Africans, Blacks, Whites, Coloureds and Indians to come out in large numbers to support the \#ZumaMustFall campaign and send out a loud and strong message to Zuma and the ANC that, he is not the correct person and leader that South Africa requires in the midst of our fragile economy. It's time that Zuma falls and departs from the South African political landscape. The above expose touched on the political intrigue of South African politics under a Machiavellian President and, touched on his 2016 state of the Nation address, which was nothing but the same old rhetoric with no action plan to implement his announcements.

3.1.18 The Objective Reality of Growth in developed Economies and How It Will Affect Emerging Markets and South Africa

The world economy may be set for another year like 2015, with very modest growth in developed countries offsetting persistent weaknesses elsewhere, but generating very little inflation and keeping interest rates low The New Age, 2015). This will have a very serious impact on emerging markets that are reeling and, in the case of South Africa it will be worse, given the current economic and fiscal crisis and the possibilities of the economy being reduced to 'junk' status. The United States Federal Reserve's long - awaited rise in rates (by 25 basis points) showed confidence in the world's largest economy, but rival China is still struggling for a foothold with rate cuts. It can be confidently asserted that the Federal Reserve will be forced to further increase rates. This will then impact negatively on emerging markets and more so, on the South African economy because of its own making by an incompetent government. Although some countries, such as Brazil, have mainly home grown inflation troubles, the Fed's first post - crisis rate hike is an unlikely cure for what ails the rest of the world and particularly South Africa. The key question is whether the US economy is robust enough not only to sustain its own recovery but also to lift world trade and global growth. This is an unlikely scenario for South Africa that has sown the seeds of its own economic demise.

Finley, Cascione and Karunakar (2015) point out that "The polls point to global growth averaging only 3.4 percent next year given the slowdown in China. By the same token, along with an abrupt downturn in the volume of global trade and 
a continuing fall in commodity prices, the dollar's rise this year has brought US industrial growth to a near standstill, keeping a lid on inflation pressures from abroad." There is gloom surrounding emerging markets and South Africa must beware. China is a debt laden economy and one of the largest trading partners of South Africa on the African continent. Another serious problem for emerging markets and particularly South Africa, given the parlous nature of its economy is the reality that, if the Fed would hike rates again in March 2016, there will be very little hope for South Africa's economic recovery. Given the dictatorial and Machiavellian President's (Jacob Zuma) mismanagement of the South African economy; the country now sits on a time bomb waiting for it to explode. There does not seem that the new Finance Minister, Pravin Gordhan will be in a position to do much as time ticks by and 2016 is already, at South Africa's doorstep. Cry the Beloved Country. In projecting on the 2016 President's State of the Nation Address the following concerns were expressed by political commentators and the South African media and press. Some of these are captured hereunder as follows:

The following is now the reality:

$>$ ANC MP's have turned on Zuma. He did not listen to their advice and defied them (Makinana et al.; 2016).

$>$ The fact that he signed the pension reform legislation without consultation with the unions has now led the government to make a U - turn (Nhlabathi, 2016).

$>$ Civil defiance is now the order of the day. There were clashes in Parliament before the State of the Nation Address and thus reinforced the notion that South Africa has decended into a police state, ruled by an iron fist and a zero - tolerance policy towards civil disobedience (City Press, 2016).

$>\quad$ The unnecessary pressure to move Parliament north and out of Cape Town. The figures have not been worked out and analysts believe that it will not save money (Nhlabathi, 2016). Zuma is playing to the gallery in terms of stating that it would save money.

> The Public Protector's victory has shown-up Zuma and the ANC in terms of defending the indefensible as concerns his Nkandla homestead. (Tabane, 2016). He must pay back the money. This is not the only issue, he must resign or he must be impeached, if the Constitutional Courts ruling goes against him.

Given government policy the mining industry is in extreme and dire straits and many workers will lose their jobs (Van Rensburg, 2016).

$>$ Will South Africa in terms of a policy shifts move away from a crony state and will the pragmatists prevail (Haffajee, 2016)?

$>$ What do Zuma defenders have to say now (City Press, 2016)?

$>$ How can South Africa be saved? (Phosa, 2016).

$>$ It was a turning point in post - apartheid SA politics. What was evident at the Constitutional Court is that the ANC, which gave South Africa the Constitution, is now its debaser, rather than its protector. Is the EFF now the new guardians of the Constitution? (Gevisser, 2016).

$>$ Deputy President Cyril Ramaphosa acknowledges business fears over policy flip - flops, and the dangers of state capture. (Msomi. 2016).

> President's cutbacks will make only modest savings (Van Onselen, 2016).

$>$ President snubs 8, 3 million jobless in his speech (Hunter, 2016).

> Shocked MP's say Nkandla flip - flop could open way for impeachment, particularly if ANC MP's in Parliament consolidate democracy once and for all (Ndenze et al. (2016).

$>$ The State of the Nation Address now done, can South Africa swing into action because rating agencies want more detail on growth plans (Isa, 2016: 1).

$>$ South Africa needs action to save it, not a speech (Leoka, 2016).

$>$ Humbled Zuma goes cap in hand to big business (Speckman, 2016).

$>$ Business happy for now with biscuits and pie (Peacock, 2016).

$>$ South Africa must empower new standards to foster savvy SA investment (Peacock, 2016).

$>$ The crisis in Higher Education will get worse and, is a ticking time bomb.

$>$ The press indicates that the rest is left to the Finance Minister and perhaps he can give SA hope where Zuma fell short (Khumalo, 2016: 8). 
$>$ THE IMF has stated that South Africa must deregulate for growth and must create a level playing field for small enterprises because that is where jobs will come from (Mbanjwa, 2016).

$>$ Zuma's speech is tainted because he did not apologize to the nation (Msomi, 2016).

$>$ Cronies, leeches and a wounded Zuma (Bruce, 2016: 16).

$>$ SA farmers owe R125 billion to the banks and the President said nothing about agriculture (Bonorchis, 2016).

$>$ Zuma can't regain credibility while trying to satisfy contradictory forces (Marrian, 2016).

$>$ A speech devoid of conviction: Zuma failed to offer detailed targets for cost cuts (Editorial. Business Day, 2016).

$>$ Slip slidin' in Zuma's nation of ambiguity (Onselen, 2016).

$>$ Anglo descends into junk territory: Danger for South African mining. (Business Day. 2016). Anglo American credit rating was cut to junk by Moody's Investor Service and has damaged its ability to pay its debt. It is now downsizing and will affect the South African mining industry. The President did not talk to mining problems in South Africa, especially about the downswing in commodity prices (Bloomberg, In Business Day. Business Report (2016). On the other hand, the Presidents hand - picked Minister of Mineral Resources disappointed the top players with his outlook in respect to mining problems in South Africa and globally and he could not offer how South Africa plans to heal the industry's ills given the crisis in mining within the country (Seccombe, 2016).

$>$ Denel, Gupta venture illegal: Minister and Treasury did not grant permission for the Tie Up (Proves the economic and political influence of the Gupta's, Zuma's crony capitalism (Business Day, 2016).

$>$ Makhaya, T. (2016). Zuma's reluctant shot at realism. (Opinion. Business Day, February 16, Johannesburg. Republic of South Africa, 13).

$>$ The debate on the State of the Nation speech saw the opposition hammer the president and the democratic Alliance, the EFF and other parties called for Zuma's resignation with immediate effect (SABC, ANN7 and other TV Broadcasters, 2016. Prime Time News).

$>$ Inflation and rate hike to hammer SA banks (Khuzwayo, 2016).

$>$ Poverty to rise as South Africa flirts with recession - report (Maswanganyi, 2016).

$>$ South Africa's rating downgrade risks mount amid policy risks (Business Report, Khuzwayo and Faku, 2016).

$>$ Irresponsible law making is costing SA dear (The Times. Editorial. 2016: 12).

$>$ President Zuma has no idea as to how the economy works: His cynical take on markets. (Business Day, 2016).

$>$ Factory slump threatens growth (Maswanganyi, Business Day, 2016).

$>$ Zuma did not factor into the equation that Goldman Sachs bets against the rand (Justin Brown, 2016).

$>$ The ANC, the President and the Cabinet are maxed out: SA's debt headache is not understood by politicians (Farber and Jordan, 2016).

$>$ Commentators indicate that the out of tune Zuma and the ANC must not make excuses because the state of the global economy is no excuse for inaction in South Africa (The Times, 2016).

$>$ South African Television Stations, ENCA, SABC, and ANN7 (2016: Prime Time News). "Reported that Zuma's 2016 State of the Nation Address was a rehash of the 9 step plan for economic revival outlined in his 2015 speech and, this added nothing to economic revival because the 2015 plans have not in the main been actioned by the government and, therefore, South Africa sits in the same quagmire as the economy worsens." The nation is being taken for granted.

$>$ The above is only the tip of the iceberg and President Zuma's excesses are too many to list and there is no real acknowledgment by him, his Cabinet and the ANC that the South African economy is in tatters and is in complete shambles.

\subsubsection{What the ANC Elders Think}

Five long serving and respected elders of the African National Congress who served the ANC with distinction through the liberation struggle and were also victimized and jailed by the apartheid state and, a few served in the Cabinet and the democratic administration post democracy in 1994, had this to say:

1. "Frank Chikane: On October 4, 2015, the former Secretary General of the South African Council of Churches and former Director General in President Thabo Mbeki's government said "For the ANC to remain a winning ANC, it 
must keep the tradition of being self - critical. Failure to do so will result in its demise, and it losing confidence and its position as leader of society.

2. Mavuso Msimang: On October 19, 2015, the former revolutionary stalwart said that "Recognizing that the organization needs a vigorous shake-up is a good place to start on the journey to reclaim what was once our moral high ground. Also essential is that people allowing themselves to think and act fearlessly. Credibility will elude us if we do not walk the talk.

3. Barbra Hogan: ANC comrade with impeccable revolutionary credentials and who held two Cabinet positions in democratic South Africa as, Minister of Health and also Minister of Public Enterprises and, married to struggle hero Ahmed Kathrada who was incarcerated in Robbin Island Prison for 26 years, by the apartheid government and, who was the closest ally and friend of former President Nelson Mandela, saw his wife fired from her Cabinet position because she chose to speak truth to power and for criticizing the ANC said "I certainly believe that if the ANC members are worth their salt, they have to start looking very carefully and introspectively _ _ about our roles in this organization and what we are giving consent to by allowing this president to operate as though he is completely unaccountable.

4. Ben Turok: On December 14 the former struggle stalwart and former retired Member of Parliament in the democratic government said that "Jacob Zuma has made the worst possible decision of his entire career as a president by axing Nhlanhla Nene.

5. Denis Goldberg: On January 26, 2016 in London; the former Treason Trial accused and Rivonia Trialist charged with high treason by the apartheid government said that "Let us focus on the needs of our people, not on our needs as new political leaders with access to power - and therefore, wealth and personal enrichment which robs us of our freedom" (Mathews Phosa, former Treasurer General of the ANC. 2016).

These are but only a few utterances of struggle heroes in the liberation of South Africa, there are more unhappy voices who feel and state that, the ANC under President Zuma has let not only the ANC down but the nation and, has compromised the ANC tradition and its revolutionary credentials and, feel that either President Zuma resigns or that, he must be booted out of office or be re - called by the ANC, impeached by Parliament for his many indiscretions and, for compromising the Constitution of the Republic and, for compromising his oath of office. If this is done, South African democracy will be on the path of consolidation and recovery.

\subsubsection{South African Business "Disappointed" by President Zuma's 2016 State of the Nation Address}

In typical Zuma tradition in delivering his yearly State of the Nation Address (SONA) over several years, since 2009 when he assumed office, there was much lip service and nothing tangible that he gave South Africa in terms of a turnaround strategy, in order to take remedial action for an economy that he single - handedly destroyed and continues to do with the sanction of his many Cabinet appointees, who he has appointed through the processes of overt and vulgar patronage. "Disappointed" is the general sentiment of business leaders and investors in the wake of President Zuma's state of the nation address reports City Press (2016). This is the verdict of business even after the Minister of Finance and the President met with South African business leaders a few days before he delivered his address. The Finance Minister lectured business on the following issues: 1. "the media needs to explain the global economy better for a South African audience. 2. What responsibility do we take for our own environment? 3. If we do not act collectively on ratings we will all pay the costs. 4 . Business is beginning to think in social democratic terms - business leaders are developing empathy. 5. We need a new psyche to create dynamism on the ground. 6. There are lots of differences. Can we focus on our similarities? 7. The financial markets and the real world move on different trajectories. 8. South Africa's big - four challenges are: social cohesion; inequality; anti-racism and non - racialism; investment ratings. 9. Why do workers spend 30 percent to 40 percent of their income on transport? (A poor question when one considers that public transport must be a government responsibility) 10 . We have a developmental state but not an implementation state. 11. There is a common sense of crisis - and there are huge opportunities in a crisis. 12. Everyone's in recession (This is no excuse). Business' key issue was that the National Development Plan (NDP) is not being implemented, and among many other reasons growth is stagnating" (City Press, 2016).

The Minister of Finance said nothing new. He spat out the jargon that South African delegation presented at the most recent economic meeting at Davos, Switzerland, which was received at Davos with luke-warm reception. The President of South Africa did not pitch at a crucial meeting and Davos concentrated on Mauritius and Nigeria. South Africa stood alone and no one was interested in South Africa. According to Justin Brown (2016) "President Jacob Zuma touched on many key issues that business told him they wanted addressed, but his state of the nation address left local corporates and investors disappointed." Opposition political parties were not impressed because the President did not outline a definite plan to turn around a bleeding economy and his speech lacked implementation and action detail. As usual the ruling ANC paid the President high accolades, singing his praises. This was laughable in a crisis. 
Justin Brown (2016) states that "Shoprite chairperson Christo Wiese told the SABC that he was looking for something more dramatic from the President. There was a need for South Africa to focus less on global problems and get our affairs in order. The country would have to suffer some pain to get things on the right track. Peter Montalto, an economist (In Justin Brown, 2016:3) with Nomura in London said that "The key for us was the total lack of any new thinking in wider government policy to boost growth. There was only a limited recognition of the current economic malaise __ There was no 'rabbit out of a hat' moment." Mbete, a lecturer at the Department of Political Sciences at the University of Pretoria said "her sense was that President Zuma had largely aimed his speech to business. Despite this, there were very few numbers, details or specifics in the speech. It is bizarre not to mention numbers. By the same token, Andile Khumalo, Power FM managing Director (In Justin Brown, 2016) said that "Zuma did not cover any of the substantial economic points. Does the President understand the economy?" Jan Sluis - Cremer (In Justin Brown, 2016) said that "A Rand Merchant Bank currency trader, the Rand had been sold off later in anticipation that SONA would produce a shock or something unexpected. There was nothing in SONA, so the Rand firmed a bit on Friday, but remains stuck in a range between R15.75 and R16.25 against the US dollar.” The CEO of Business Unity South Africa (In Justin Brown, 2016) said that "The points that business had raised with Zuma earlier included stimulus projects, job creation, especially in the small, medium and micro enterprise sector, the credit rating, strong fiscal discipline and increasing levels of tax. Zuma skirted around this issue but did not mention the black industrialist scheme in his speech." Justin Brown (2016) said that "On the topic of fiscal discipline Zuma said government had undertaken to spend funds wisely and to cut wasteful expenditure, but without compromising on the core business of government and the provision of services and that the Finance Minister will elaborate on these issues in his 24 February, 2016 Budget Speech. The leader of the opposition Democratic Alliance (In Justin Brown, 2016) said "Zuma could not just cut food and travel costs; he also needed to reduce the size of his Cabinet and could have already saved R4.2 billion by doing so." Turning to the country's credit rating, Zuma said "Our country seems to be at risk of losing its investment grade status from ratings agencies" (SONA, 2016). This is the reality created by his Machiavellian behaviour.

Power FM's Khumalo said that "It would appear that Zuma failed to send a signal to the rating agencies to avert a downgrade and Kristin Lindow, Moody's lead sovereign analyst for South Africa. Said "President Zuma's state of the nation address acknowledged the country's deep economic challenges and provided hints of future budget savings. The markets' attention in the short term will turn to the $2016 / 17$ budget _ _ and whether the measures announced will succeed in steadying confidence" (In Justin Brown, 2016). Kweyama (In Justin Brown, 2016) expressed concern about "The management of state - owned enterprises and to our bewilderment Zuma said that the dysfunctional state - owned enterprises, the President glossed over the issue and said that, many of them were performing well. This was playing to the gallery and Business Day (2016: 1) said that "a report on state - owned enterprises was sitting with Zuma since 2013 and that, he now released the report which calls for partial privatization of these state - owned enterprises, a day after his state of the nation address. In reality, nothing tangible will occur in this regard because, there has to be consultation with the labour unions before it can be actioned. In all possibility the unions will not agree. It will be an area of extreme confrontation. These are loss making entities and must be sold outright, rather than bailing them out year after year, to lift the burden from the state and the taxpayer. In other words they are relics of the former apartheid state and, the democratic government is papering over the cracks and, just cannot bite the bullet to rid itself of these loss making entities. Zuma chose the example of the South African National Roads Agency Limited, which is subject to scrutiny related to its failed e-tolls project which is costing the state billions of Rands to service debt incurred in building costs. The immigration policy was a key for local business, including its effects on tourism and on attracting skilled workers. He said that a draft migration policy will be presented to Cabinet during the course of 2016. Too little too late. All done and said, the President did not touch on pressing social issues and his performance was a damp squib, nothing but idle rhetoric. The nation therefore waits with bated breath for the Minister of Finance to present his 2016 $/ 2017$ budget on the $24^{\text {th }}$ of February, 2016. The issue is will he be able to steady a sinking economic ship and will he be able to avoid a downgrade to junk status. Time will only tell.

\subsubsection{The People State Why Zuma is Losing Power}

Moshesha (2016:4) outlines the people's reaction as to why Zuma is losing power. The reasons are as follows:

$>$ He lacks leadership and managerial skills.

$>\mathrm{He}$ is an operative, not a manager.

$>$ He enjoys the assurance he gets for his decisions by his cronies.

$>$ He understands, thrives and takes advantage of "African gullibility."

$>$ His biggest enemy are the people around him, which is of his own making.

$>$ They regard him as the goose that lays the golden eggs. 
$>$ The advice they give is driven by the rewards they will receive.

$>$ It was the e - tolls, followed by the Marikana massacre, the expulsion of Nene, hiring incompetent people to key portfolios, the signing of an act to control workers' pensions, the lack of decisiveness to fire dead wood ministers and a host of blunders on a continuing basis.

$>$ Arrogance, ignorance and a lack of education.

$>$ Personal self - interest and self - enrichment without due regard for the country he leads."

3.1.22 What do Zuma Defenders Have to Say?

The City Press (2016) summarizes this as follows:

$>$ Those who defended President Jacob Zuma knew very well they were not being honest. How can we trust them in future if they can't serve the country with honesty and integrity? Let them vacate those offices on their own. How disgraceful.

D They must apologies to the nation for insulting and lying to us, and simply resign and go home.

> We all knew that Zuma was supposed to pay back the money. The defenders also knew they were taking the nation for a ride.

$>$ It is high time they realize that we may be silent, but we do know what is right.

> Implicated ministers and bureaucrats including the Minister of Police must go now and never return to government. They must be expelled as members of the ANC.

$>$ All those ministers who wasted our tax money to remorselessly defend lies and shamelessly declare blatant lies must face immediate expulsion.

$>$ Zuma must be criminally charged he broke his oath of office and defiled the Constitution of the Republic."

In short the people have spoken and to this end the ANC must listen to the people and ask Zuma to resign immediately.

3.1.23 Drought and Rand Fragility are Worsening Economic Slowdown and Moody's Downgrade Growth to 0.5 Percent from 0.8 Percent: Junk Status Economy is Now Almost Inevitable

The Business Day (2016) states that "Weak economic growth or a recession would see ratings agencies downgrade the economy of the country to the so-called junk status. Moody's said "That this will happen in the next 12 to 18 months." It further stated that "The worst drought on record in South Africa _ _ is aggravating the ongoing economic slowdown, threatened a near zero growth, if not recession. It downgraded the economy to 0.5 percent growth for 2016." Moody's currently rates SA at Baa2 with a negative outlook. Other ratings agencies rated South Africa even lower - two levels above speculative grade or junk status. According to Maswanganyi (2016) "The prolonged drought puts SA more at risk of recession" South Africa has fallen short of growth and Moody's downgraded the economy once again and said that growth in 2017 would stand at 1.5 percent. The issue is simple, the government and the President only mentions agriculture when tabling the land issue which is an unpopular measure in respect of investment. According to Joffe (2016: 10) "The President of South Africa is out of tune with reality because his State of the Nation Address, did not mention the devastating effects of drought upon the economy and, this was left to Moody's to sight as a risk for both an entry into recession and a downgrade by ratings agencies. South Africa sits in a precarious situation now and has to do something to avoid both a recession and a downgrade."

\section{Conclusions}

$>$ The narrative brought home the pitfalls of poor governance in South Africa by the ANC led government and an incompetent and Machiavellian President, political patronage and corruption that permeate the political landscape of South Africa, under the ANC led government.

$>$ It brought home the worsening economic and fiscal crisis of South Africa, and a lack of understanding basic economics and the markets by a president that is taking South Africa to its economic demise and supported by the majority of ANC politicians.

$>$ Given the current body politic in democratic South Africa, the issue that needs to be addressed is - Why should some people hunger for the dehumanizing apartheid experience. It is our duty to ensure that sound and honest leadership continues to assert itself.

$>$ That, under the present government South Africa is on a road of destruction economically. It will become all the more difficult for the poor to survive because the country is in the midst of economic ruin and the cost of living is becoming all the more unbearable. 
$>$ There is a rise in unemployment which the government cannot contain, leading to increased poverty and the burden of widening inequality.

$>$ Public services are in disarray with an unproductive and inefficient bureaucracy, coupled with the rise in public servant salaries that now make up about 60 percent of GDP.

$>$ Under the current government there are increased strikes in almost all sectors of the economy because of a lack of service delivery.

$>$ The sacking of Finance Minister Nene cannot be explained and is only defended by the ANC led government.

$>$ Some individuals have tremendous influence and play a part in pressurizing the President to take unreasonable mammoth decisions that places the economy on the road to ruin and destruction.

$>$ The government has a propensity to spend without having the money to do so and corruption has become endemic. The rich, the governing elite and politicians are becoming richer while the masses are becoming poorer.

$>$ That the country in 2016 will experience a recession, inflation will rise significantly, government will be forced to raise interest rates and the economy will be downgraded to “junk' status by rating agencies.

$>$ In all probability South Africa will look to the IMF to bail it out.

$>$ The markets and investors will have no confidence in the economy of South Africa.

$>$ Capital Flight will increase and so will the levels of crime.

$>$ The Machiavellian President just does not have a clue as to how a capitalist economy functions and does not understand the issues of globalization and the impact that all of this has on an emerging market like South Africa.

$>$ The time has come for a change in President and possibly a change in government, after two decades of so called democracy led by the ANC government that has destroyed the economy of the country.

$>$ The effects of mismanagement of the economy and the dire fiscal constraints will only reveal itself in 2016.

\section{Recommendations}

It is necessary that an in depth study be undertaken by researchers in terms of the high and low roads to development and economic recovery, in a country yearning for sound and honest governance with politicians that must reflect honesty and integrity in running the country. It is hoped that further recommendations will be developed by researchers undertaking such a study outlined in the section, areas for further research.

\section{Conclusion}

The narrative outlined the economic and fiscal consequences that South Africa was placed into by its President Jacob Zuma, in firing a competent Finance Minister without tangible reasons, which devastated the South African economy. Quiet clearly, he just does not understand in the long protracted global economic crisis, as to how capitalism functions and operates. Clearly, the South African Machiavellian President Jacob Zuma, overplayed his hand and ruined the South African economy, failed to understand the market reaction to firing the Minister of Finance, has taken the citizens of the country for granted and, clearly does not understand capitalism, sophisticated economic models and failed to understand capital flow and its winding pathways. The time has arrived for a change of leadership in order to save the country and, place it on a path of economic recovery, growth and prosperity. A change of President is essential. His State of the Nation speech inspires little confidence for a nation that is crying out for sound leadership. The Machiavellian debacle has wreaked havoc on the economy of South Africa. It does not matter, even if the economy of South Africa staves of a downgrade, the reality is that the economy is in tatters and this will take years to recover, while poverty increases, the rich and ruling elite will get richer, and there will be increasing inequality and even higher unemployment. This is the reality at present and will continue for a long time to come under the ANC led government.

\section{References}

Aitnay, G. (2015). What is this infatuation with elites? Mail and Guardian. Comment and Analysis. December 11 to 17. Read as Background Reading. Johannesburg. Republic of South Africa, 25.

Alec, H. (2016). Extracted from Africa Confidential: Named: Van Rooyen's two Gupta “advisors" who almost hijacked SA Treasury. February 15. Johannesburg. Republic of South Africa and London, 1 - 5).

Alec, H. (2016). Extracted from Africa Confidential: On Ian Whitley. February 16. Johannesburg. Republic of South Africa and London, 1.

Amabhungane Reporters (2015). Nene joins Myeni’s pile of victims. Mail and Guardian. Master of Chaos. December 11 to 17 . Johannesburg. Republic of South Africa, 4. 
Azikiwe, A. (2015). Political Struggle Mounts over the Future of South Africa. Global Research. Johannesburg. Republic of South Africa, 1-3.

Balfour, R. J. (2015). Middle class rules, but can it lead? Mail and Guardian. December 18 to 22. Read as Background Reading. Johannesburg, Republic of South Africa, 33.

Bonorchis, R. (2016). SA farmers owe R125 billion to the banks. Independent. Business Report. January 18. Johannesburg. Republic of South Africa, 1.

Brown, J. (2016). “Disappointed.” City Press. Business. February, 3.

Brown, J. (2016). Goldman Sachs bets against the rand. Business Report. January 14. Johannesburg. Republic of South Africa, 1.

Bruce, P. (2016). Cronies, leeches and a wounded Zuma. Sunday Times. February 14. Johannesburg. Republic of South Africa, 16.

Brummer, S. (2015). Nuclear price tag set Nene against Zuma: The overall costs are staggering. Mail and Guardian. December 18 to 22. Read as Background Reading. Johannesburg. Republic of South Africa, 4.

Burger, P., Calitz, E., \& Siebrits, K. (2016). Business Day. Opinion. Read as Background Reading. Johannesburg. Republic of South Africa, 11.

Business Day (2016). Anglo descends into junk territory. February 16. Johannesburg. Republic of South Africa, 1.

Business Day (2016). A speech devoid of conviction: Zuma failed to offer detailed targets for cost cuts. Editorial. February 15. Johannesburg. Republic of South Africa, 10.

Business Day (2016). Denel, Gupta venture illegal: Minister and Treasury did not give permission for the tie - up. February 16. Johannesburg. Republic of South Africa, 1.

Business Day (2016). Zuma's cynical take on markets. Editorial. January 12. January 12. Johannesburg. Republic of South Africa, 10.

Business Day (2016). Zuma's reluctant shot at realism. Editorial. February 16. Johannesburg. Republic of South Africa, 13.

Business Day. (2015). Into the Abyss. Johannesburg. Republic of South Africa, 1.

Business Times (2016). Worse than we thought: IMF slashes SA's growth estimate in half - to just o.7 percent. January 20. Johannesburg. Republic of South Africa, 6.

Business Day (2016). Drought and rand fragility are worsening economic slowdown, Moody's says. February 16. Johannesburg. Republic of South Africa, 1.

Calland, R. (2015). There are limits to your power, Mr. President. Mail and Guardian. Comment and Analysis. December 18 to 22. Johannesburg. Republic of South Africa, 21.

Carol, P. (2015). Cabinet gives green light to nuclear procurement. Business Day. December 14. Johannesburg. Republic of South Africa, 1.

City Press (2016). The Gordhan - CEO conversation. Business. February 14. Johannesburg. Republic of South Africa, 3.

City Press (2016). What do Zuma defenders have to say? City Press. February 14. Johannesburg. Republic of South Africa, 4.

City Press (2016). What Other ANC Elders Think? City Press. February 14. Johannesburg. Republic of South Africa, 3.

Claire, B. (2015). Weak rand and fragile markets brace for Fed hike. Business Day, 2. Johannesburg. Republic of South Africa, 2.

Cohen, M., \& Potelwa, X. (2015). Nene's removal spooks investors: Economic cluster to meet on ratings, falling rand. The Sunday Independent. Business Report. December 13. Read as Background Reading. Johannesburg. Republic of South Africa, 1.

Craig, D. (2015). Gordhan Appointed. Zuma in a dramatic backdown. The Mercury. December 14. Read as Background Reading. Durban. Republic of South Africa, 1.

David, H. (2011). The Enigma of Capital And the Crises Of Capitalism. First South African Edition (2011). Profile Books Limited. Exmouth House. Pine Street. London ECIR OJH.

Davids, N., \& Cornelius, J. (2016). ‘A no - brainer’, says Cape Town. Sunday Times. February 14. Johannesburg. 
Republic of South Africa, 4.

De Wet, P., \& Sole, S. (2015). The nuclear deal is a minefield. Mail and Guardian. December 11 to 17. Johannesburg. Republic of South Africa, 6.

Dictionary.com (2016). The meaning of Machiavellian. 1979 and 1986 Harper Collins,s 1560 - 1570. Dictionary.com (htttp://dictionary.reference.com/).

Dineo, F. (2015). Business watches from the sidelines. Business Report. December 14. Read as Background Reading. Durban. Republic of South Africa, 1.

Dlamini, P., \& Mahlangu, D. (2015). Van Rooyen 'bad for ANC in polls'. The Times. Johannesburg, Republic of South Africa, 4.

Dodds, C. (2015). SA business leaders express their concern. The Sunday Independent. Politics. December 13. Read as Background Reading. Johannesburg. Republic of South Africa, 4.

Donnelley, L., \& Lisa, S. (2015). Nene bombshell shatters SA. Mail and Guardian. Business. December 11 to 17. Johannesburg. Republic of South Africa, 1.

Donnelly, L. (2015). Gordhan's mettle will be tested. Mail and Guardian. Governance. December 18 to 22. Johannesburg. Republic of South Africa, 3.

Editorial (2015). \#ZumaMustFall - hold the racism. Mail and Guardian. Comment and Analysis. December 18 to 22. Johannesburg. Republic of South Africa, 22.

Editorial (2015). Nene axing: JZ scorns economy. The citizen. Opinion. December 11. Johannesburg. Republic of South Africa, 12.

Editorial (2015). Never mind Van Rooyen. Is Zuma right for the job? The times. Opinion. December 11. Read as Background Reading. Johannesburg. Republic of South Africa, 12.

Editorial (2015). President's ninth life beckons _ _ _ but at what cost? Sunday Times. December 13. Johannesburg. Republic of South Africa, 20.

Editorial (2015). Who will stop the wrecking ball? Mail and Guardian. Comment and Analysis. December 11 to 17. Johannesburg. Republic of South Africa.

Editorial (2015). Zuma's Goliath blunder. Sunday Tribune. Opinion. December 13. Read as Background Reading. Durban. Republic of South Africa, 22.

Editorial (2015). Public outrage signals need for change at top. The Sunday Independent. December 16. Read as Background Reading. Johannesburg. Republic of South Africa, 16.

Ellis, M. (2015). Market crisis, Fed set to test Bank. Business Report. December 14. Analysis. Read as Background Reading. Durban. Republic of South Africa, 1.

ENCA, SABC, ANN7 (2016). Zuma rehashes the 2015 State of the Nation Address in his 2016 address: Nothing new. South African Television, Prime Time News. February 15. Johannesburg. Republic of South Africa.

Farber, T., \& Jordan, B. (2016). Maxed out: SA’s debt headache. Sunday Times. Johannesburg. Republic of South Africa, 1.

Finley, R., Cascione, S., \& Karunakar, R. (2015). No sign of major pick - up in world economy in 2016. Business Report. International. London and Bengaluru. December 22. Durban. Republic of South Africa, 14.

Gevisser, M. (2016). Barbarians at the Gate. City Press. February 14. Johannesburg. Republic of South Africa, 13.

Ginindza, B., \& Mnyandu, E. (2015). More turmoil looms in the economy. The Sunday Independent. Business Report. December 13. Read as Background Reading. Johannesburg. Republic of South Africa, 1.

Govender, S. (2016). Time to tighten that belt? Not if it's Louis Vuitton. Sunday Times. February 14. Johannesburg. Republic of South Africa, 10.

Haffajee, F. (2016). Did 9/12 knock us back to our senses? City Press. Voices. February 14. Johannesburg. Republic of South Africa, 1.

Hilary, J. (2016). Moody's talks drought as Zuma falls short on growth. Business Day. February 17. Johannesburg. Republic of South Africa, 10.

Hunter, Q. (2016). President snubs 8.3 million jobless in his speech. Sunday Times. February 14. Johannesburg. Republic of South Africa, 4. 
Jan - Jan, J. (2015). Treasury smear was a warning. Sunday Times. December 13. Johannesburg. Republic of South Africa, 6.

Johnson, R. W. (2015). Gordhan no Horatius on bridge, SA firmly on path of bankruptcy. Thought Leaders. December 16. Johannesburg. Republic of South Africa.

Ka Nkosi, S. (2015). SA wakes up from fairytale as spin doctors fail. Business Report. Opinion and Analysis. December 14. Read as Background Reading. Durban. Republic of South Africa, 2.

Khumalo, A. (2016). The rest is up to you, Pravin! Sunday Times. Business Times. Opinion. February 14. Johannesburg. Republic of South Africa, 8.

Khuzwayo, W. (2015). Widening trade gap knocks rand. Business Report. December 1. Read as Background Reading. Johannesburg. Republic of South Africa, 1.

Khuzwayo, W., \& Faku, D. (2016). SA's rating downgrade risks mount amid policy concerns. Business Report. January 22. Johannesburg. Republic of South Africa, 1.

Leoka, T. (2016). SA needs action to save it, not a speech. Sunday Times. Business Times. February 14. Johannesburg. Republic of South Africa, 2.

Letsoalo, M., \& Pressly, D. (2015). Business on plot against Zuma, says Lindiwe Zulu. Mail and Guardian. December 18 to 22. Johannesburg. Republic of South Africa,s $1-2$.

Letsoalo, M. (2015). ANC's allies demand to be consulted. Mail and Guardian. December 11 to 17. Johannesburg. Republic of South Africa, 5.

Letsoalo, M. (2015). Nene axing a warning to Cyril: Behave. Mail and Guardian. Master of Chaos. December 11 to 17. Johannesburg. Republic of South Africa, 2.

Lisa S. (2015). Economic apocalypse averted. Mail and Guardian. Business. December 18 to 22. Johannesburg. Republic of South Africa, 1.

London (2015). Slight growth in developed economies expected next year. The New Age. Johannesburg. Republic of South Africa, 13.

Magubane, K. (2015). Academics criticize Nene's axing. Business Day. December 14. Johannesburg. Republic of South Africa, 3 .

Makinana, A., \& Nhlabathi, H. et al. (2016). ANC MPs turn on Zuma. City Press. February 14. Johannesburg. Republic of South Africa, 1.

Malala, J. (2016). They talk of service to the poor but walk with the rich and powerful. The Times. January 18. Johannesburg. Republic of South Africa Page 13. Khuzwayo, W. (2016). Inflation and rate hike to hammer SA banks. Business Report. February 16. Johannesburg. Republic of South Africa, 1.

Malan, M. (2015). No quick fix for NHI. Mail and Guardian. December 11 to 17. Johannesburg. Republic of South Africa, 6 .

Maluleka, T. (2015). Words fail us after Zuma's latest disaster. Mail and Guardian. Comment and Analysis. December 18 to 22. Read as Background Reading. Johannesburg. Republic of South Africa, 24.

Manuel, T. (2015). Manuel hints at 'outside hand' in Nene's dismissal. Wire Staff. http://www.bdlive.co.za/national/2015/12/21/manuel-hints. Investors Monthly. Business Day Live. Johannesburg. Republic of South Africa,s 2 to 6.

Mariam, I. (2015). Pain and pressure: Zuma's Christmas gift to the economy. Sunday Times. Business Times. December 13. Johannesburg. Republic of South Africa, 1.

Mariam, I. (2016). Not bad, Mr. President - now let's swing into action. Sunday Times. Business Times. Johannesburg. Republic of South Africa, 1.

Marrian, N. (2015). Axing to hit life savings hard, stock exchange boss warns. Business Day. December 14. Johannesburg. Republic of South Africa, 1.

Marrian, N. (2016). Zuma can't regain credibility while trying to satisfy contradictory forces. Business Day. February 15. Johannesburg. Republic of South Africa, 3.

Masombuka, S. (2015). Van Rooyen was 'a miscalculation' - Gordhan. The Times. Johannesburg. Republic of South Africa, 1.

Maswanganyi, N. (2016). Factory slump threatens growth. Business Day. February 2. Johannesburg. Republic of South 
Africa, 1 .

Maswanganyi, N. (2016). Poverty to rise as South Africa flirts with recession - report. Business Day. February 3. Johannesburg. Republic of South Africa, 1.

Mbanjwa, X. (2016). Deregulate for growth: The World Bank. Read as Background Reading. City Press. Business. Johannesburg. Republic of South Africa. February 14, 2.

Mbele, G. (2016). These shoes ain't made for walking: Rather late than not wearing that number. Sunday Times. February 14. Johannesburg. Republic of South Africa, 5.

McKune, C. (2015). Will captain Gordhan steer SAA back on course. Mail and Guardian. December 18 to 22. Read as Background Reading. Johannesburg. Republic of South Africa, 4.

Mercury, C. (2015). Zuma axes Nene, rand plummets. The Mercury. December 10. Durban. Republic of South Africa, 3.

Mngxitama, A. (2015). Vitriol flies as country falls apart. The Sunday Independent. Dispatches. December 13. Read as Background Reading. Johannesburg. Republic of South Africa, 14.

Moatshe, R. (2015). Judge me on my actions, pleads Van Rooyen, but market 'taught Sa a lesson. The Star. Politics. Read as Background Reading. December 16. Johannesburg. Republic of South Africa, 4.

Modjadji, N., \& Slabbert, A. (2015). Nene drama: rand bleeding. The citizen. December 11. Read as Background Reading. Johannesburg. Republic of South Africa, 3.

Msomi, S. (2016). Ramaphosa: 'We heard you, loud and clear” Sunday Times. February 14. Johannesburg. Republic of South Africa, 4.

Msomi. S. (2016). Zuma's speech tainted by the elephant herd in the room. Sunday Times. February 14. Johannesburg. Republic of South Africa, 17.

Mthombothi, B. (2015). Zuma blunder gives SA the chance to cross its new Rubicon. Sunday Times. December 13. Johannesburg. Republic of South Africa, 21.

Ndenze et al. (2016). ANC outrage over Zuma's Thuli U - turn. Sunday Times. February 14. Johannesburg. Republic of South Africa, 5.

Ndenze, B. (2016). Lekota: "I simply had to walk out" Sunday Times. February 14. Johannesburg. Republic of South Africa, 4.

Ngwenya, F. (2015). Finance Minister takes over tough job. Business Report. Opinion and Analysis. December 14. Read as Background Reading. Durban. Republic of South Africa, 2.

Nhlabathi, H. (2016). Government's pension reform U - turn. City Press. February 14, Johannesburg. Republic of South Africa, 2.

Nicky, N. K. (2015). It's not just the numbers, it hurts ordinary citizens. Business Report. Opinion and Analysis. December 14. Read as Background Reading. Durban. Republic of South Africa, 2.

Nkosi, B. (2015). Will \#FeesStillFall? Mail and Guardian. December 11 to 17. Read as Background Reading. Johannesburg. Republic of South Africa, 6 .

Onselen, G. (2016). President's cutbacks will make only modest savings. Sunday Times. February 14. Johannesburg, Republic of South Africa, 4.

Onselen, G. (2016). Slip slidin' in Zuma's nation of ambiguity. Business Day. February 15. Johannesburg. Republic of South Africa, 12.

Peacock, B. (2016). Business happy for now with biscuits and pie. Sunday Times. February 14. Johannesburg. Republic of South Africa, 3.

Peacock, B. (2016). “empowering' new standard to foster savvy SA investment. Sunday Times. Business Times. February 14. Johannesburg. Republic of South Africa, 6.

Phosa, M. (2016). How can we save South Africa? City Press. Voices. February 14. Johannesburg. Republic of South Africa, 3.

Pohamba, H. (2015). Africa can reach its potential if more leaders put people first. Mail and Guardian. Comment and Analysis. December 11 to 17. Read as Background Reading. Johannesburg. Republic of South Africa, 25.

Rampedi, P., Jika, T., \& Hofstatter, S. (2015). 'We think it's all about this women. Sunday Times. December 13. 
Johannesburg. Republic of South Africa, 6.

Readers Forum (2015). The time is ripe to ring the bells for Zuma to fall. Business Report. Opinion and Analysis. December 14. Read as Background Reading. Durban. Republic of South Africa, 2.

SABC (2016). Rand slides to its lowest level ever. Prime Time News. January, 11, 2016. Johannesburg. Republic of South Africa.

SABC, ANN7 and Other TV Broadcasters (2016). Opposition Parties call for Zuma's Resignation with Immediate Effect. February 16. Johannesburg. Republic of South Africa. Prime Time News.

Sathekge, B. (2015). Volatile rand flirts with junk credit status. The New Age. December 22. Read as Background Reading. Johannesburg. Republic of South Africa, 13.

Seccombe, A. (2016). Zwane disappoints at gloomy global indaba. Business Day. February 9. Johannesburg. Republic of South Africa, 1.

Skiti, S., Shoba, S., Jika, T., \& Prinsloo, L. (2015). Nene: I Did It For SA. Sunday Times. December 13. Read as Background Reading. Johannesburg. Republic of South Africa, 1.

Soko, M., Zuma is sowing the seeds of his own demise. Sunday Times. Opinion and Analysis. December 13. Johannesburg. Republic of South Africa, 16.

Speckman, A. (2016). Humbled Zuma goes cap in hand to big business. Sunday Times. Business Times. February 14. Johannesburg. Republic of South Africa, 3.

Templeton, A. (2015). Government "crosses line" with finance minister axing. The citizen. Business. December 11. Johannesburg. Republic of South Africa, 33.

Thabi, R. Surviving SA's worst president since apartheid. Sunday Times. Fire. December 13. Read as Background Reading. Johannesburg. Republic of South Africa, 16.

Thakali, T. (2015). Van Rooyen "a man with an elephant skin. The Sunday Independent. Politics. December 13. Read as Background Reading. Johannesburg. Republic of South Africa, 4.

Thakali, T., \& Political, B. (2015). Zuma in bid to quell the Nene fires: President in late - night talks to appease upset alliance partners. The Sunday Independent. December 13. Johannesburg. Republic of South Africa, 1.

Thakali, T., \& Political Bureau. (2015). Nene's Russian roulette: Zuma acted to save R 1trillion nuclear promise to Putin. Sunday Tribune. December 13. Durban. Republic of South Africa, $1-2$.

The Times (2016). Irresponsible law making is costing South Africa dear. Editorial. February 3. Johannesburg. Republic of South Africa, 12.

The Times (2016). State of global economy no excuse for inaction in South Africa. Editorial. January 15. Johannesburg. Republic of South Africa, 14.

The Times, Editorial. (2015). To Zuma, all the sound and fury signifies nothing. December 14. Read as Background Reading. Johannesburg. Republic of South Africa, 12.

What the People said (2016). Why is Zuma losing power? City Press. February 14. Johannesburg. Republic of South Africa, 4.

Wild, S. (2015). Curse of 'toxic' workers. Mail and Guardian. Human Resources. December 11 to 17. Johannesburg. Republic of South Africa, 13.

Williams, D. (2015). Everybody (except the ANC) slams JZ over ill - timed sacking. The citizen. December 11. Johannesburg. Republic of South Africa, 3.

Zibi, S. Zuma' economy - wrecking legacy. Business Day. Review and Opinion. December 14. Johannesburg. Republic of South Africa, 1.

\#ZumaMustFall (2015). The political rollercoaster ride. Hehehe\#ZumaMustFall. Eyewitness News (@ewnupdates). December 11. Johannesburg. Republic of South Africa, 2.

\section{Copyrights}

Copyright for this article is retained by the author(s), with first publication rights granted to the journal.

This is an open-access article distributed under the terms and conditions of the Creative Commons Attribution license (http://creativecommons.org/licenses/by/3.0/). 